\title{
A 100-Year Review: Advances in goat milk research ${ }^{1}$
}

\author{
Stephanie Clark ${ }^{2}$ and María Bárbara Mora García \\ Food Science and Human Nutrition, lowa State University, Ames 50011-0152
}

\begin{abstract}
In the century of research chronicled between 1917 and 2017, dairy goats have gone from simply serving as surrogates to cows to serving as transgenic carriers of human enzymes. Goat milk has been an important part of human nutrition for millennia, in part because of the greater similarity of goat milk to human milk, softer curd formation, higher proportion of small milk fat globules, and different allergenic properties compared with cow milk; however, key nutritional deficiencies limit its suitability for infants. Great attention has been given not only to protein differences between goat and cow milk, but also to fat and enzyme differences, and their effect on the physical and sensory properties of goat milk and milk products. Physiological differences between the species necessitate different techniques for analysis of somatic cell counts, which are naturally higher in goat milk. The high value of goat milk throughout the world has generated a need for a variety of techniques to detect adulteration of goat milk products with cow milk. Advances in all of these areas have been largely documented in the Journal of Dairy Science (JDS), and this review summarizes such advances.
\end{abstract}

Key words: adulteration, composition, nutrition, somatic cells, safety

\section{INTRODUCTION}

Previously considered the "poor man's cow," the goat - and goat milk products - began gaining attention in the United States in the 1960s because of health and nutritive values attributed to goat milk and milk products. Touted for its easy digestibility and lower allergenic properties compared with cow milk, goat milk has been considered a nutraceutical for decades, but many early reports were anecdotal. The Journal of Dairy Science (JDS) played a large role in documenting the true differences between cow and goat milk.

Received June 4, 2017.

Accepted July 21, 2017.

${ }^{1}$ This review is part of a special issue of the Journal of Dairy Science commissioned to celebrate 100 years of publishing (1917-2017).

${ }^{2}$ Corresponding author: milkmade@iastate.edu
Haenlein (1980) even credited JDS as "a major US research organ on dairy goats as well as on dairy cows." In the 100-year period since 1917, JDS has published more than 850 research manuscripts related to goat milk and milk products. However, these numbers do not reflect the full scope of research related to dairy goats, or the role that goat milk and milk products have played in advancing the global dairy industry in the past century. With particular focus on JDS publications, this paper is dedicated to those discoveries (Appendix Table A1).

\section{ADVANCES IN GOAT MILK RESEARCH FROM 1917 TO 2017}

\section{Goat Milk and Human Nutrition}

The importance of goats for human nutrition has likely been recognized since the beginning of domestication. Indeed, the first publications related to goat milk, published in The Lancet, tended to focus on infant feeding and some of the risks and benefits associated with it (Dalebrook, 1902; Blackham, 1906; Cahill, 1906; Wright, 1906). One letter to the editor of The Lancet claimed that "goats practically never have tubercle, therefore their milk can be given without pasteurizing... their milk is said to be better for infants than cow's milk because the curd is finer" (Edmunds, 1914). Prompted by the observation that goat milk rarely forms a cream layer, though its fat content was similar to that of cow milk, Schultz and Chandler (1921) reported that 91\% of goat milk fat globules were $<4 \mu \mathrm{m}$ in diameter. Previous work by Bitting (1902) reported that $90 \%$ of cow milk fat globules were $>4 \mu \mathrm{m}$ in diameter. Although it soon became clear that goat milk was also susceptible to microbial contamination, the softer curd and higher proportion of small fat globules have been selling points of goat milk ever since these early works.

In the early $1900 \mathrm{~s}$, vitamins and minerals were almost exclusively studied in rats, chicks, and monkeys. Approximately 15 years before the early "Our Industry Today" report by Elvehjem (1953), work in his laboratory revealed that rats grew more slowly on goat milk than on cow milk. By then, several cases of severe anemia had been associated with goat milk feeding of human infants, and the term "goat's milk anemia" was 
coined. Elvehjem (1953) reported that goat milk provided inferior amounts of vitamin $\mathrm{B}_{12}$ and that levels of folic acid in goat milk and cow milk were "about equal" (which has since been shown untrue). However, because improvement in rat growth was seen with folic acid supplementation, a sparing effect of folic acid on vitamin $\mathrm{B}_{12}$ was indicated. Still in the early days of understanding the role of folic acid and $\mathrm{B}_{12}$ in human health, Collins et al. (1953a,b) published 2 companion papers in JDS, the former related to cow colostrum and milk, and the latter to goat colostrum and milk. Because vitamin $\mathrm{B}_{12}$ levels in sheep milk could be increased by the addition of cobalt or trace minerals (containing cobalt), Harper et al. (1951) wanted to evaluate the effect of such diet supplementation in goats. Goats that received trace-mineralized salt (containing cobalt) had a higher level of vitamin $\mathrm{B}_{12}$ in their colostrum and milk during the first week postpartum compared with those receiving only iodized salt. Trace-mineralized salt or a $50-\mathrm{mg}$ supplement of cobalt per goat per day had no influence on the level of $\mathrm{B}_{12}$ in goat milk after this time. The addition of trace minerals to the diet of the goat did not influence the free folic acid level of the goat milk. The authors admitted that the information reported in the JDS work was "more accurate" than that reported in their previous work (Collins et al., 1951).

It was not realized until later that goat milk was deficient, with respect to human nutrition, in folic acid and vitamins $\mathrm{B}_{12}$ and $\mathrm{B}_{6}$, nutrients that are essential for normal human infant development (Ford and Scott, 1968; Parkash and Jenness, 1968). Nonetheless, goat milk products gained considerable attention in the 1970s because of their perceived health and nutritive value. Jenness (1980) provided a good review of goat milk nutritive value based upon the literature of the time. Similar to cow milk, goat milk is an adequate-toexcellent source of protein, calcium, niacin, pantothenic acid, phosphorus, potassium, riboflavin, thiamin, and vitamin A to the human diet (Parkash and Jenness, 1968; Jenness, 1980). Neither cow nor goat milk is a good source of iron, vitamin C, or vitamin D (unless fortified). In contrast to cow milk, goat milk contains inadequate levels of vitamin $\mathrm{B}_{6}$, vitamin $\mathrm{B}_{12}$, and folic acid for infant nutrition (Ford and Scott, 1968; Parkash and Jenness, 1968; Jenness, 1980). Folic acid and vitamin $\mathrm{B}_{12}$ deficiencies became a focus of research in the 1970s regarding megaloblastic anemia in children exclusively fed goat milk (Davidson and Townley, 1977) and continue to be of concern today (Ziegler et al., 2005; Basnet et al., 2010).

One of the main characteristics of goat milk that has contributed to its appeal as an alternative to cow milk is its lower allergenic properties compared with cow milk. Even today, families are known to switch to goat milk or to buy a dairy goat to avoid cow milk consumption. Yet mostly anecdotal evidence for the lower allergenicity of goat milk was reported until the 1990s (Loewenstein et al., 1980; Haenlein, 2001). With an incidence of 2 to $3 \%$ in the first year of life, cow milk allergy is the most common food allergy in early childhood, but the remission rate is approximately 85 to $90 \%$ by adulthood (Høst, 2002). In an outstanding review published in JDS, Jenness (1980) noted that in many cases, allergy to cow milk proteins was not improved by shifting patients to goat milk, and he recognized that $\alpha_{S 1}$-casein may play a role. It was not until Ballabio et al. (2011) published in JDS that the clear relationship was established. By running individual milk samples from 25 goats with different $\alpha_{\mathrm{S1}}$-CN genotypes through SDS-PAGE and immunoblotting using monoclonal antibodies specific for bovine $\alpha-C N$ and sera from children allergic to cow milk, Ballabio et al. (2011) showed that goat milk allergenicity is a function of $\alpha_{\mathrm{S}_{1}} \mathrm{CN}$ genetic polymorphism. Lower reactivity was shown for samples with null $\alpha_{S 1}$ CN genotypes $\left(0_{1} 0_{1}\right.$ or $\left.0_{1} \mathrm{~F}\right)$. Their work confirmed that caution must be taken before goat milk is suggested as an alternative to cow milk for patients with cow milk allergy. They went further to indicate that goat milk from particular $\alpha_{S 1}-\mathrm{CN}$ genotypes could serve as protein sources for hypoallergenic formulas (Ballabio et al., 2011). The findings were echoed by Lisson et al. (2014), who confirmed that although genetic variants of caseins differ in their allergenicity, cross-reactivity of IgE antibodies of goats and buffaloes with cow milk caseins limit feeding goat or buffalo products to cow milk-allergic patients.

In "Past, present, and future perspectives of small ruminant dairy research," Haenlein (2001) provided an outstanding review of over 135 manuscripts related to, primarily, goats and sheep. Haenlein noted that research before 2001 was scarce on the unique qualities of goat and sheep milk compared with cow milk; largely it had been assumed that technical research on cows could be extrapolated to small ruminants. Haenlein summarized differences in anatomy, physiology, nutrition, metabolism, and pathology of goats and sheep, as well as differences in their milk and milk products and economic profitability. Although not mentioned in his manuscript, perhaps a dairy goat check-off program could help narrow the gap of disparity in research dollars spent on cows and dairy goats. Particularly compelling was Haenlein's statement regarding the potential of goat or sheep milk to combat under- and malnutrition of people in poor areas and countries. Only 21 out of the 24 countries Haenlein included in his summary met the recommended level of calcium intake $(1,000$ $\mathrm{mg} / \mathrm{d}$ ). All but 5 countries met the recommended level of protein consumption $(50 \mathrm{~g} / \mathrm{d})$ in the form of animal 
protein (developed countries); 6 countries had below or borderline levels of protein consumption even after plant sources of protein were included. The bottom line is that many countries have room to improve animal protein and milk utilization. In his conclusion, Haenlein (2001) urged continued research, extension service, and public support to improve the productivity of small ruminant dairy animals, particularly in developing nations that rely on these animals to a much greater extent than developed nations.

In recent years, epidemiological studies have led investigators to consider estrogen a factor that may contribute to reproductive system cancers (Yager and Davidson, 2006; Farlow et al., 2009). The World Cancer Research Fund/American Institute for Cancer Research (2007) demonstrated no relationships of importance for consumption of milk and cancer, with the exception of colorectal (decreased risk) and prostate (increased risk) cancers. Because of concerns about estrogen metabolites in milk and consumption being associated with cancers of the reproductive system (Farlow et al., 2009), Farlow et al. (2012) compared estrone $\left(\mathrm{E}_{1}\right)$ and $17 \beta$-estradiol $\left(\mathrm{E}_{2}\right)$ levels in commercial goat and cow milk. Goat milk exhibited a lower combined concentration of $\mathrm{E}_{1}$ and $\mathrm{E}_{2}$ than cow milk.

\section{Goats Serve as Surrogates to Cows}

The earliest JDS manuscript that specifically mentioned dairy goat milk was published in volume 15, in May 1932, titled "Fat metabolism in the lactating goat" (Bender and Maynard, 1932). Similar to the sister manuscript, published in volume 17 in March 1934, titled "The effect of specific dietary fats on the blood lipids of lactating goats" (Williams and Maynard, 1934), both manuscripts stated that dairy goats were selected for research to save expense, rather than to study dairy goat metabolism in particular. The authors explicitly stated an assumption that, physiologically, dairy goats and dairy cows would perform similarly. It is surprising that in those early works, adequate sample size and replication were not required for publication. Findings for 4 goats, that received 4 different dietary treatments, were reported in the Bender and Maynard (1932) manuscript. Cunningham and Addington (1936) destined goats to be "used more and more in fundamental research problems" because of their convenient size - equating them with 5 to 7 dairy cows - and greater offspring potential. Since these early works, it has been realized that caution must be exercised when using the goat as a model for the dairy cow (Larson 1978), and dairy goats and their milk are worthy of study in their own right.

\section{ADVANCES IN GOAT MILK COMPOSITION RESEARCH}

Bergman and Turner (1937) were among the first to report on the composition of dairy goat colostrum, in particular, the globulins (importantly associated with immune bodies). They reported a rapid transition of colostrum (characterized by high total solids, fat, and total protein) from 6 Toggenburg does into nearly normal milk by d 3 and 4 after parturition. At the time, total protein was composed of 4 groups of protein: casein, casein globulin, albumin, and globulin. They used the "newer methods of protein analysis," including precipitation with $8 \%$ trichloroacetic acid for determination of total protein, and casein precipitation with an acetate buffer solution, to quantitatively determine total protein, free from nonprotein nitrogen and casein. By salting out with $\mathrm{MgSO}_{4}$, Bergman and Turner (1937) were able to track globulin and albumin separately, for the first time. The most rapid change was seen in globulin, which was reported to decrease from $1.76 \%$ on d 1 to $0.40 \%$ on d 2 , and $0.11 \%$ by d 9 . Because albumin did not decrease to the same extent, globulin was determined to be the driver in protein transition between colostrum and normal milk.

Until 1940, only 4 research manuscripts reported goat milk composition data (Bosworth and Van Slyke, 1916a,b,c; Lythgoe, 1940). Lythgoe (1940) conducted proximate analysis on 335 samples from individual goats from 21 herds in Massachusetts, across a 16-mo period. The results are summarized in Table 1. The work confirmed the high individual and seasonal variability in total solids (driven primarily by high variability of fat), which was more pronounced in goats than in cows. Fifteen years later, in another early JDS "Our Industry Today" literature review, Rusoff (1955) included a table comparing milk composition of various mammals (Table 2). The information was from the second edition of The Market Milk Industry (Roadhouse and Henderson, 1950). In subsequent years, a few manuscripts related to goat milk composition were published. Jenness (1980) compiled the mean total solids, fat, CP, lactose, and ash from milk of international goat breeds from 11 references reported in 9 countries between 1968 and 1979. At the time Jenness (1980) wrote his review, the composition of milk from individual US goat breeds still had not been reported; oddly, milk from pygmy goats was used to represent US goat milk composition. It was not until Alderson and Pollak (1980) summarized 3,481 milk and fat yield records of Alpine, LaMancha, Nubian, Saanen, and Toggenburg goats from a cooperating herd in California, that we gained an appreciation for the differences in milk com- 
100-YEAR REVIEW: GOAT MILK RESEARCH

Table 1. Analysis of 355 individual goat milk samples from 21 herds, collected across 16 mo (adapted from Lythgoe, 1940)

\begin{tabular}{|c|c|c|c|c|c|c|c|}
\hline Month & $\begin{array}{c}\text { Total } \\
\text { solids }(\%)\end{array}$ & $\begin{array}{l}\text { Fat } \\
(\%)\end{array}$ & $\begin{array}{c}\text { Solids } \\
\text { nonfat }(\%)\end{array}$ & $\begin{array}{c}\text { Lactose } \\
(\%)\end{array}$ & $\begin{array}{c}\text { Proteins } \\
(\%)\end{array}$ & $\begin{array}{l}\text { Ash } \\
(\%)\end{array}$ & $\begin{array}{l}\text { Protein:fat } \\
\text { ratio }\end{array}$ \\
\hline December and January & 14.5 & 5.08 & 9.42 & 4.78 & 3.99 & 0.84 & 0.78 \\
\hline February & 14.56 & 5.13 & 9.43 & 4.87 & 3.97 & 0.85 & 0.78 \\
\hline May, June, and July & 12.24 & 3.79 & 8.45 & 4.66 & 3.34 & 0.77 & 0.86 \\
\hline August & 11.44 & 3.37 & 8.07 & 4.32 & 2.99 & 0.78 & 0.89 \\
\hline September & 12.29 & 3.98 & 8.31 & 4.49 & 3.16 & 0.79 & 0.82 \\
\hline
\end{tabular}

position and milk production of US dairy goat breeds. Milk and fat yield were influenced by age, month, and year of freshening, and Nubians had the lowest yields but highest fat content (3.8\%). Haenlein (1981), who evaluated the production records of US dairy goats, also showed that milk from Nubians had the highest fat content $(4.6 \%)$ and lowest yield $(806 \mathrm{~kg} / 305-\mathrm{d}$ record).

More recently, Guo et al. (2001) collected commingled commercial goat milk shipments for an entire year to provide fundamental information for cheese making and milk cheese yield potential and pricing. Samples were collected weekly from bulk milk shipments to a commercial cheese plant from April 1996 to March 1997. The bulk milk was composed of milk from 12 dairy farms, including the Saanen, Nubian, LaMancha, Alpine, and Toggenburg breeds, in New Hampshire and Vermont. Total solids and fat contents decreased over the first 20 wk from 12.7 and $3.6 \%$ to 11.3 and $3.0 \%$, respectively, and then increased to peak values of 13.4 and $4.4 \%$ in January. The contents of $\mathrm{CP}$ and casein also decreased in the first $20 \mathrm{wk}$, from 3.5 and $2.7 \%$ to 3.2 and $2.3 \%$, respectively, and then increased gradually to 3.8 and $2.9 \%$ in February. The physicochemical properties of commingled goat milk (in Table 3) were adapted from Table 1 in Guo et al. (2001). Summer milk had the highest yield potential per kilogram of protein, due to a higher proportion of casein in $\mathrm{CP}$; late-lactation milk from does that freshened in the summer had the lowest yield potential. Guo et al. (2001) also concluded that, because of the high lactational and seasonal variability, milk standardization, especially in February, would enable greater uniformity in cheese composition and functionality.

Table 2. Average composition of milk of various mammals (adapted from Roadhouse and Henderson, 1950)

\begin{tabular}{lccccc}
\hline Species & $\begin{array}{c}\text { Total } \\
\text { solids }(\%)\end{array}$ & $\begin{array}{c}\text { Fat } \\
(\%)\end{array}$ & $\begin{array}{c}\text { Lactose } \\
(\%)\end{array}$ & $\begin{array}{c}\text { Protein } \\
(\%)\end{array}$ & $\begin{array}{c}\text { Ash } \\
(\%)\end{array}$ \\
\hline Human & 12.57 & 3.70 & 6.98 & 1.63 & 0.21 \\
Cow & 13.10 & 4.00 & 4.90 & 3.50 & 0.70 \\
Goat & 12.86 & 4.09 & 4.20 & 3.71 & 0.78 \\
Camel & 12.39 & 5.40 & 3.30 & 3.00 & 0.70 \\
Sheep & 16.43 & 6.18 & 4.17 & 5.15 & 0.93 \\
\hline
\end{tabular}

A viral disease that causes animal and economic losses in goat production throughout the world is caprine arthritis encephalitis (The Center for Food Security and Public Health, 2007). The lentivirus responsible for caprine arthritis encephalitis disease is caprine arthritis encephalitis virus (CAEV), which affects animals in the form of chronic progressive arthritis, pneumonia, chronic weight loss, encephalomyelitis, and indurative mastitis (Kaba et al., 2012). Because contradictory results have been shown for milk production studies, Kaba et al. (2012) investigated the influence of CAEV on milk yield, SCC, and percent fat, protein, and lactose in a 12-yr cohort study with 177 does. No significant differences were found between infected and uninfected animals for daily milk yield or SCC (non-leukocytic epithelial cell-like particles). However, the milk of uninfected goats contained more total protein, fat, and lactose than that of the infected goats. Martínez-Navalón et al. (2013) studied the Marciano-Granadina breed, which commonly carries CAEV. Longer lactations, higher milk yield, higher fat content, normalized mean SCC, and lactose content were found in seronegative goats. According to their findings, CAEV infection could be a major cause for decreased milk production in dairy goats; however, they mentioned that transmission routes and potential causes of this disease are still unclear and need more research (Martínez-Navalón et al., 2013).

Table 3. Physicochemical properties of commingled goat milk (adapted from Guo et al., 2001)

\begin{tabular}{lccc}
\hline Item & $\mathrm{N}$ & Mean $\pm \mathrm{SD}$ & Range \\
\hline Fat (\%) & 50 & $3.61 \pm 0.47$ & $3.00-4.40$ \\
Lactose (\%) & 50 & $4.47 \pm 0.15$ & $4.13-4.73$ \\
CP (\%) & 50 & $3.47 \pm 0.21$ & $3.19-3.86$ \\
Casein (\%) & 50 & $2.57 \pm 0.15$ & $2.34-2.86$ \\
NPN (\% of CP) & 49 & $5.04 \pm 0.34$ & $4.40-5.65$ \\
Total solids (\%) & 50 & $12.38 \pm 0.71$ & $11.17-13.44$ \\
Ash (\%) & 50 & $0.82 \pm 0.04$ & $0.79-0.89$ \\
$\mathrm{Ca}(\%)$ & 50 & $0.15 \pm 0.01$ & $0.12-0.17$ \\
$\mathrm{P}(\mathrm{mg} / \mathrm{kg})$ & 50 & $0.13 \pm 0.02$ & $0.10-0.16$ \\
$\mathrm{Na}(\mathrm{mg} / \mathrm{kg})$ & 49 & $672 \pm 125$ & $380-977$ \\
$\mathrm{Mg}(\mathrm{mg} / \mathrm{kg})$ & 49 & $160 \pm 24$ & $100-217$ \\
Zn (mg/kg) & 49 & $4.59 \pm 1.93$ & $1.30-9.50$ \\
Specific gravity & 50 & $1.0235 \pm 0.0007$ & $1.0224-1.0262$ \\
\hline & & &
\end{tabular}




\section{Studies with Somatic Cells}

Similar to dairy cows, mastitis is the primary and most costly infection of dairy goats, and dairy goat mastitis research published in JDS has been extensive in the past 4 decades (Timms and Schultz 1985; Contreras et al., 1997, 2003; Moroni et al., 2005; Koop et al., 2010, 2012; Gelasakis et al., 2016). Summary of such work is beyond the scope of this review. However, although high SCC are strongly associated with mastitis in cows, that is not always the case with goats (Dulin et al., 1983; Park and Humphrey, 1986; Koop et al., 2012). It has long been known that the milk of goats naturally contains elevated levels of somatic cells compared with cows, because of the apocrine secretory system in the mammary gland, and that, for cows, elevated SCC are associated with cheese quality defects (Dulin et al., 1982, 1983; Poutrel and Lerondelle, 1983; Park, 1991; Zeng and Escobar, 1996). But because bacterial cell counts do not explain high SCC in goat milk (Park and Humphrey, 1986), the effect of SCC on goat cheese has been debated. Dulin et al. (1982) studied the differentiation and enumeration of SCC in goat milk. Results indicated that cytoplasmic particles that are similar in size to milk somatic cells, and commonly found in goat milk, can be mistakenly counted as somatic cells by milk quality machines. Therefore, it was recommended to use counting methods that are DNAspecific for estimation of somatic cells in goat milk to have an accurate differentiation of cells from cell-like material. Zeng (1996) compared SCC and chemical composition of goat milk using Fossomatic-300 (Foss, Hillerød, Denmark) and Dairylab II (Multispec Ltd., Weldrake, York, UK), calibrated either with goat milk or cow milk. In both machines, SCC estimation in goat milk was higher when cow milk was used as a standard than with goat milk as a standard. Moreover, results significantly exceeded legal limits established by the US Food and Drug Administration (1,000,000 cells/mL for goat milk at the time compared with the 750,000 cells/ $\mathrm{mL}$ limit for cows (US DHHS-PHS-FDA, 2015). Zeng (1996) indicated that the natural differences between cow and goat milk can lead to SCC, protein, and fat reading errors by milk quality equipment when they are set up with cow milk as a standard. Therefore, he recommended using goat milk as a standard when testing goat milk quality to collect reliable data.

Somatic cells, and their impact on cow milk quality, have been extensively studied. Factors such as milking methods, breed, age, stage of lactation, season, and management have been reported to affect SCC in cow milk; however, it is not always the case in goat milk (Zeng and Escobar, 1996). Milk from Nubian and Alpine dairy goats and 3 milking methods (pipeline, bucket, and hands) were tested to compare SCC, standard plate count (SPC), and chemical milk composition during a complete lactation (Zeng and Escobar, 1996). There was no significant difference among milking methods, but SCC increased as lactation advanced and SPC was higher in Nubian milk than in Alpine milk. Milk fat and protein of both breeds increased during the first $60 \mathrm{~d}$ of lactation and then decreased. Some milk samples contained over 1,000,000 somatic cells/ $\mathrm{mL}$, which exceeded the legal limit for grade "A"; nevertheless, does did not experience mastitis symptoms such as swelling or redness of udder. A pathology test indicated that staphylococci were the predominant bacteria, but there was no mastitis condition. Therefore, healthy does could produce milk with more than $1,000,000$ cells/mL and the grade "A" SCC rule should be reviewed to truly reflect goat udder health. In a more recent study with 60 Alpine goats not exhibiting clinical mastitis, Chen et al. (2010) demonstrated that milk composition did not change when $\mathrm{SCC}$ varied from 214,000 to 1,450,000 cells/mL. Milk with higher SCC actually had a lower SPC. Coliform and psychrotrophic bacteria counts, milk components (fat, protein, lactose, casein, and total solids), and yield of semisoft goat cheese did not differ among low-, medium-, and high-SCC goat milk. However, body and texture scores provided by trained panelists were lower and free fatty acids (FFA) were higher for high cheeses made with milk with highest SCC (Chen et al., 2010). Today, the grade "A" Pasteurized Milk Ordinance allows 1,500,000 cells $/ \mathrm{mL}$ for goat milk and 750,000 cells $/ \mathrm{mL}$ for cow, sheep, and camel milk (US DHHS-PHS-FDA, 2015). Albenzio et al. (2015) went deeper into goat physiology with their research into activities of indigenous proteolytic enzymes in goat milk of different SCC. They identified 700,000 cells $/ \mathrm{mL}$ as the threshold for changes in the immune status of the goat mammary gland. Similar to findings cow and sheep, plasmin appeared to be the predominant enzyme activity in goat milk, which was correlated with SCC and macrophages in particular (Albenzio et al., 2015).

It is important to note that the other temperature, chemical, physical, and bacteriological standards for grade "A" raw milk and grade "A" pasteurized milk and milk products do not differ for cow and goat milk (US DHHS-PHS-FDA, 2015). Goats and goat milk and milk products are held to the same high standards for safety and quality that the dairy industry is known for.

\section{Findings with Fatty Acids}

By 1964, the overall significance of short-chain fatty acids (FA) in ruminant milk fat was not fully known, but it was recognized that goat milk had unique flavor 
Table 4. Fatty acid composition (mol \%) of milk fat triglycerides (up to $\mathrm{C}_{20: 0}$ ) of 5 species (adapted from Breckenridge and Kuksis, 1967)

\begin{tabular}{|c|c|c|c|c|c|}
\hline Fatty acid & Human & Jersey cow & Holstein cow & Goat & Sheep \\
\hline $4: 0$ & - & 9.8 & 8.5 & 8.2 & 10.3 \\
\hline $6: 0$ & - & 5.0 & 2.9 & 6.9 & 3.4 \\
\hline $8: 0$ & - & 2.4 & 1.4 & 5.8 & 2.3 \\
\hline 10:0 & 0.6 & 4.8 & 2.3 & 7.9 & 3.4 \\
\hline $12: 0$ & 3.0 & 4.1 & 2.1 & 1.9 & 1.8 \\
\hline $14: 0$ & 5.3 & 11.8 & 7.5 & 2.6 & 5.0 \\
\hline $15: 0$ & 0.6 & 1.7 & 1.2 & 0.7 & 0.9 \\
\hline $16: 0$ & 26.5 & 36.5 & 28.0 & 16.0 & 20.9 \\
\hline $16: 1$ & 4.0 & 1.1 & 1.6 & 1.2 & 1.2 \\
\hline $16: 2$ & - & - & - & - & - \\
\hline $17: 0$ & 1.1 & 0.8 & 0.7 & 2.4 & 2.9 \\
\hline $18: 0$ & 7.8 & 8.6 & 14.6 & 14.3 & 15.5 \\
\hline $18: 1$ & 37.6 & 13.0 & 26.5 & 30.4 & 27.2 \\
\hline $18: 2$ & 10.0 & 0.4 & 1.5 & 1.7 & 2.9 \\
\hline $18: 3$ & 0.6 & - & - & - & 2.4 \\
\hline $20: 0$ & - & - & Trace & - & Trace \\
\hline
\end{tabular}

properties. Efthymiou and Mattick (1964) developed a domestic feta cheese to provide uniformity to the unpredictable quality of feta cheeses that were being produced in the United States at the time. Although feta cheese is traditionally made from goat or sheep milk, their method was developed to produce characteristics of "typical Greek Feta" using cow milk. The authors concluded that characteristic (desirable) rancid flavor, specifically from FFA $\mathrm{C}_{2}$ to $\mathrm{C}_{10}$, could be consistently produced using a mixed culture of Streptococcus (now Lactococcus) lactis and either Lactobacillus casei or Lactobacillus acidophilus, and lipase powder - either Capalase-KL (kid- and lamb-derived; Dairyland Food Laboratories Inc., Waukesha, WI) or CapalaseL (lamb-derived pregastric esterase). Bitter, atypical rancid, and unclean flavors were associated with the use of Capalase-K (kid-derived) or Italase (calf-derived; Dairyland Food Laboratories Inc.), and FA of $\mathrm{C}_{12}$ or higher chain length predominated.

As the recognition of unique properties of goat milk, particularly FA, grew, Dimick and Patton (1965) set out to understand the role of butyric acid and its function in milk fat synthesis. It had previously been reported in JDS articles (Jensen et al., 1961; Jack et al., 1963), that butyrate was esterified at the $s n-1$ and $s n-3$ positions in triglycerides. For their experiments, they used fresh raw milk from cows (herd milk) and goat (1 animal) milk. Their work demonstrated similarities in molar percent distribution of FA from each of the triglyceride fractions, with maximum butyrate concentrations being $20.4 \mathrm{~mol} \%$ (goat) and $20.0 \mathrm{~mol} \%$ (cow), yet they determined that few, if any, dibutyryl triglycerides exist in either type of milk. Ultimately, the authors concluded that butyrate exists predominantly as $1 \mathrm{~mol} / \mathrm{mol}$ of triglyceride in both cow and goat milk. Freeman et al. (1965) later reported, in JDS, the distribution of FA in goat, sheep, Indian buffalo, cow, and human milk using methyl esters via GLC. The short-chain $\mathrm{FA} \mathrm{C}_{4: 0}$ and $\mathrm{C}_{6: 0}$ were shown to be esterified predominantly in the $s n-1$ and $s n-3$ positions in all species. The $\mathrm{C}_{14: 0}$ and $\mathrm{C}_{15: 0}$ FA were preferentially esterified at the $s n-2$ position, whereas $\mathrm{C}_{18: 0}$ was primarily esterified at $s n-1$ or $s n-3$ positions. Shortly thereafter, Breckenridge and Kuksis (1967), utilizing butyl esters in GLC, revealed the FA distribution of milk from 7 species (Table 4). Differences in the findings between Freeman et al. (1965) and Breckenridge and Kuksis (1967) were attributed to methodology (methyl vs. butyl esterification) and milk sources.

Attaie and colleagues (1993) were the first to investigate FA profiles of cow and goat colostrum. Simultaneous distillation extraction was used to separate short-chain from long-chain FA, and the $n$-butyl esters of FA were quantified by GC and identities confirmed by GC-MS. Table 5 displays the concentration of total FA in goat and cow colostrum. Similar to milk of goats and cows, significant differences in colostrum FA profile were generally found between species. However, the amounts of hexanoic, octanoic, decanoic, 9-decenoic, and dodecanoic acids also differed between goat breeds, with Nubian goats presenting more of each of the aromatic compounds.

Chilliard and colleagues (2003) provided an excellent review on the nutritional and physiological factors affecting goat milk lipid synthesis and lipolysis. In contrast to cows, goat milk fat content increases with almost all studied fat supplements; however, the response of fatty acid composition is similar in the 2 species. Although the lipoprotein lipase (LPL) system of goat milk is lower than that of cow milk, it is more bound to the fat globules (compared with casein micelles in cows) and more strongly correlated with 
spontaneous lipolysis (lipolysis at $4^{\circ} \mathrm{C}$ ) in goat milk. The activity of LPL is influenced by stage of lactation, milking frequency, fasting, and lipid supplementation (Chilliard et al., 2003). The lipolysis and characteristic goat milk flavor were attributed to a combination of goat milk FA composition, triglyceride structure (i.e., high proportion of $\mathrm{C}_{6}$ to $\mathrm{C}_{10} \mathrm{FA}$ esterified on carbon 3), and LPL characteristics. The authors also suggested fat supplementation of diets to improve goat milk composition for greater control of cheese processing and sensory properties (Chilliard et al., 2003).

Bouattour et al. (2008) showed that feeding a moderate level of soybean oil ( $6 \%$ as fed in the concentrate) to dairy goats increased total milk fat, conjugated linoleic acid (cis-9,trans-11 $\mathrm{C}_{18: 2} \mathrm{CLA}$ ), and trans-vaccenic acid (trans-11 $\mathrm{C}_{18: 1}$ ) in milk without negative effects on intake, milk yield, or protein content. In the same issue of JDS, Luna et al. (2008) reported increases in $\alpha$-linolenic acid, CLA, vaccenic acid, and minor CLA isomers in the milk of goats fed whole linseed and sunflower oil. Subsequently, Chen et al. (2009) demonstrated that feeding a dietary supplement containing trans-10, cis-12 CLA (3 to $6 \mathrm{~g} / \mathrm{d}$ per goat) reduced milk fat synthesis in dairy goats and decreased cheese moisture and yield. Martínez Marín et al. (2012) fed increasing amounts of 3 plant oils (linseed oil, high oleic sunflower oil, and regular sunflower oil) to dairy goats. Oil supplementation decreased the level of SFA in milk fat (especially $\left.\mathrm{C}_{16: 0}\right)$ and increased MUFA and PUFA in a linear manner. Supplementation with linseed oil appeared to be the most favorable alternative of the 3 because of the positive effect on rumenic acid and vaccenic acid and decrease in the n-6 to n-3 FA ratio in milk fat (Martínez Marín et al., 2012). Toral et al. (2015) set out to compare lipid metabolism of goats and cows. Animals were fed diets containing no additional oil (control), or supplements of fish oil, sunflower oil and wheat starch, in a $3 \times 3$ Latin square design, with 26 -d experimental periods. Their work demonstrated interspecies differences in mammary lipogenesis, suggesting a lower sensitivity to the inhibitory effects of trans-10, cis-12 CLA in goats and indicating that ruminal biohydrogenation pathways are more stable and less prone to diet-induced shifts toward trans-10-containing intermediates in goats than in cows.

With the emergence of biorenewable sources of fuel has come the production of by-products such as dried distillers grains with solubles (DDGS), a by-product of the ethanol industry. A good amount of literature is available on the effect of DDGS feeding on poultry, swine, beef, dairy cows, and even cow milk and cheese (Sankarlal et al., 2015; Testroet et al., 2015). Cais-Sokolińska et al. (2015) were the first to report on the effect of DDGS on goat and sheep milk and milk products, when they evaluated formation of volatile compounds in the fermented beverage kefir. Their work showed that the increased polyunsaturated fats resulting from DDGS feeding resulted in significant changes to the fermentation process and aroma profile of the resulting kefirs (Cais-Sokolińska et al., 2015).

\section{EVOLUTION OF GOAT MILK ENZYME RESEARCH}

The enzyme composition of ruminant milk was not completely characterized by 1968 and it probably is still not fully characterized. Chandan et al. (1964) reported the lysozyme content of human milk in Nature, and then proceeded to report on the composition of lysozyme, lipase, and ribonuclease in the milk of 5 species in JDS (Chandan et al., 1968). There was interest in lysozyme due to the discovery that human milk had nearly 3,000 times the amount of lysozyme than cow milk, with potential implications for infant feeding and the keeping quality of milk. The investigators confirmed the great discrepancy in lysozyme content of human milk $(40,000 \mu \mathrm{g} / 100 \mathrm{~mL})$ compared with

Table 5. Concentration (mean, $\mu \mathrm{g} / \mathrm{g}$ of fat) ${ }^{+}$of total fatty acids in colostrum of goats and cows (adapted from Attaie et al., 1993)

\begin{tabular}{lccc}
\hline Fatty acid & Nubian goats $^{1}$ & Alpine goats & Holstein cows $^{2}$ \\
\hline Butanoic acid & $304.51^{\mathrm{A}}$ & $202.67^{\mathrm{A}}$ & $226.12^{\mathrm{A}}$ \\
Hexanoic acid & $385.66^{\mathrm{A}}$ & $239.44^{\mathrm{B}}$ & $235.45^{\mathrm{B}}$ \\
Heptanoic acid & $5.31^{\mathrm{A}}$ & $4.63^{\mathrm{A}}$ & $4.46^{\mathrm{A}}$ \\
Octanoic acid & $520.68^{\mathrm{A}}$ & $297.80^{\mathrm{B}}$ & $162.28^{\mathrm{B}}$ \\
4-Ethyloctanoic acid & $13.66^{\mathrm{A}}$ & $12.52^{\mathrm{A}}$ & $10.46^{\mathrm{A}}$ \\
Decanoic acid & $1,513.70^{\mathrm{A}}$ & $766.99^{\mathrm{B}}$ & $256.10^{\mathrm{C}}$ \\
9-Decenoic acid & $36.22^{\mathrm{A}}$ & $18.34^{\mathrm{B}}$ & $19.66^{\mathrm{B}}$ \\
Undecenoic acid & $10.07^{\mathrm{A}}$ & $7.26^{\mathrm{A}}$ & $3.69^{\mathrm{B}}$ \\
Dodecanoic acid & $792.72^{\mathrm{A}}$ & $437.79^{\mathrm{B}}$ & $302.35^{\mathrm{B}}$ \\
${ }^{\mathrm{A}-\mathrm{C}}$ Means in a row with the same superscript are not different $(P>0.05)$. & \\
${ }^{1}$ Means are average of 7 samples with duplicate and triplicate determinations. & \\
${ }^{2}$ Means are average of 4 samples with triplicate determinations.
\end{tabular}


cow $(13 \mu \mathrm{g} / 100 \mathrm{~mL})$, goat $(25 \mu \mathrm{g} / 100 \mathrm{~mL})$, sheep (10 $\mu \mathrm{g} / 100 \mathrm{~mL})$, and sow $(0 \mu \mathrm{g} / 100 \mathrm{~mL})$. Differences in lipase $(13,132,39,9$, and $141 \mu \mathrm{mol} / \mathrm{min}$ per $100 \mathrm{~mL}$, respectively) and ribonuclease content $(305,1,100,425$, 300 , and $30 \mu \mathrm{g} / 100 \mathrm{~mL}$, respectively) were also notable but less extreme (Chandan et al., 1964). Later, with the emergence of genetic engineering, transgenic goats were developed to express human lysozyme at $\geq 67 \%$ of the concentration found in human milk that enhanced the antimicrobial properties of goat milk to select mastitis and pathogenic microorganisms (Maga et al., 2006a; Brundige et al., 2008). Maga et al. (2006b) demonstrated that milk from the 5 transgenic goats had lower SCC but the overall component composition of the milk and milk yield were not different from controls. Additional benefits were that milk from the transgenic goats had a shorter rennet clotting time and increased curd strength.

Milk xanthine oxidase (XO) was a hot topic in the 1980s. Oster (1971) proposed an association between $\mathrm{XO}$ and atherosclerosis. Because of such concerns, Zikakis and Wooters (1980) evaluated 195 commercially processed dairy products, polarographically, for XO activity. Fluid milk, cream, powdered and evaporated milk, yogurt and ice cream, cheese, and butter from cow milk sources, as well as goat and sheep products, were evaluated. The authors reported that the XO activity of raw milk increased with storage, particularly frozen storage, and that commercial processing destroyed about $82 \%$ of XO activity compared with raw milk. Commercial processing allowed the release of XO from the milk fat globule membrane, enabling destruction. Cheeses made from goat and sheep milk (feta and imported blue) were reported to contain low to no XO activity (Zikakis and Wooters, 1980).

DeFeo et al. (1982) were among the first to distinguish differences in the LPL system between goats and cows. The importance of their research lies in the fact that hydrolytic rancidity (lipolysis) aromas and flavors from volatile FFA are influenced by native LPL, and acceptability of goat milk products is largely influenced by rancid flavors. To characterize components of the lipolytic system in goats, in part because of the unique flavor characteristics of goat milk, Chilliard et al. (1984) activated spontaneous lipolysis in goat milk. Unlike that in cow milk, LPL activity in goat milk is correlated with spontaneous lipolysis. Goat milk LPL is distributed primarily in the cream $(46 \%)$ and serum $(46 \%)$, with little activity in the caseins $(8 \%)$, in contrast to the distribution of LPL in cow milk $(6,17$, and $78 \%$, respectively). It has been shown that the LPL activity differs among breeds of goat, with evidence of genetic polymorphism influencing the functional properties of this enzyme (Badaoui et al., 2007).
Plasmin is likely the most important protease in milk because of its influence upon milk and cheese quality. Although a lot of research into the plasmin enzyme system had been conducted in cows, it was not until the early 1990s that anyone reported on the plasmin system in goats. As in cow milk, a complex plasmin enzyme system - composed of plasmin (PL), plasminogen (PG), plasminogen activators (PA), plasminogen activator inhibitors, and plasmin inhibitors - is present in goat milk (Politis et al., 1994). For the first time, Politis et al. (1994) demonstrated that tissue plasminogen activators (t-PA) were present in the casein and serum fractions of goat milk; urokinase plasminogen activators $(\mathrm{u}-\mathrm{PA})$ were present in all fractions (i.e., casein, serum, and somatic cells). Electrophoretic studies by Trujillo et al. (1997) demonstrated that plasmin hydrolyzed the same regions in $\beta$-casein in cow and goat milk. The plasmin system is also involved in mammary involution, with higher PL and PA activity in late-lactation cows (Baldi et al., 1996). Fantuz et al. (2001) evaluated the plasminogen activation system in goat milk and its relation to composition and coagulation properties toward the end of lactation. Compared with cow and sheep milk, goat milk PG activity was low but consistent with the high activity of PA. The high PL and PA activity in goat milk was negatively correlated with coagulating properties in late lactation, which was likely related to degradation of casein (Fantuz et al., 2001).

The quality of cheeses largely depends on the rate, extent, and nature of the 2 main biochemical processes involved in cheese aging: proteolysis and lipolysis. With the growing popularity of goat milk cheeses, and paucity of information regarding proteolysis and lipolysis specific to goat milk cheeses, Park (2001) published a review on the topic in JDS. Regarding proteolysis, one of the distinguishing differences between cow and goat milk is the ratio of caseins. Because of its naturally lower content of $\alpha_{\mathrm{S}^{-}} \mathrm{CN}$, goat milk has a higher proportion of $\beta-, \alpha_{\mathrm{S}^{-}}$, and $\kappa-\mathrm{CN}$ than cow milk. Consequently, goat cheeses tend to be less firm and less resistant to enzymatic degradation than cow cheeses (Park, 2001). Earlier works published in JDS by Fontecha et al. (1990), Ha and Lindsay (1991), Attaie and Richter (1996a), and Jin and Park (1995) were cited as being important for the characterization of lipolysis in goat milk cheeses.

Because the majority of goat milk cheese sold in the United States are fresh, soft cheese (chevre), and because goats are largely seasonal breeders, availability is variable. Thus, Van Hekken et al. (2005) evaluated the effect of frozen storage on the proteolytic and rheological properties of soft goat cheese. The creation and removal of ice crystals in the cheese matrix and 
the limited proteolysis of caseins resulted in only slight changes to cheese texture. Thus, the authors concluded that frozen storage of soft cheeses may be appropriate to enable year-round supply of soft goat cheese, but consumer evaluation was not conducted to confirm this.

\section{GENETIC VARIANTS OF GOAT MILK CASEINS}

The 5 principal proteins in goat milk $\left(\alpha_{\mathrm{S}^{-}} \mathrm{CN}, \alpha_{\mathrm{S}^{-}}\right.$ $\mathrm{CN}, \beta-\mathrm{CN}, \beta-\mathrm{LG}$, and $\alpha$-LA) are reported to closely resemble their homologs in cow milk (Jenness, 1980). Research at the time suggested that goat milk lacked the homolog of bovine $\alpha_{\mathrm{S} 1}-\mathrm{CN}$, the most abundant protein in cow milk. Jenness (1980) attributed goat milk's reputed more easily digested and softer curd to the lack of $\alpha_{\mathrm{S}_{1}} \mathrm{CN}$ in goat milk; yet he acknowledged that no direct experimental evidence was yet available on the subject. However, research in the late 1980s would reveal interesting findings about goat $\alpha_{\mathrm{S1}^{-}} \mathrm{CN}$. One of the first manuscripts on the topic in English journals was published in JDS: Ambrosoli et al. (1988) reported that coagulation properties (coagulation time, rate of curd formation, and curd firmness) and composition of goat milk with low and high $\alpha_{S 1}-\mathrm{CN}$ content differed. They reported that goat milk with low $\alpha_{\mathrm{S}^{-}} \mathrm{CN}$ had a shorter coagulation time, whereas milk with high $\alpha_{S_{1}-} \mathrm{CN}$ had higher levels of components and produced firmer curds. Later, Mora-Gutierrez et al. (1991) demonstrated, using isoelectric precipitation and reversed-phase HPLC, that milk from Alpine and Nubian dairy goats could be divided into low-, medium-, and high- $\alpha_{\mathrm{S}_{1}} \mathrm{CN}-$ producing groups. The authors proposed the idea of genetic regulation of $\alpha_{\mathrm{s} 1}-\mathrm{CN}$ production, stopping short of suggesting it to be a breed-specific trait. In subsequent years, it was realized that at least 10 different genetic variants influenced the $\alpha_{S_{1}}$ CN phenotype expressed, and genetic variants were associated with breeds, milk composition, and coagulation properties; those works were not published in JDS (Martin and Addeo, 1996; Clark and Sherbon, 2000). Later, it was reported that at least 16 alleles are associated with different rates of $\alpha_{\mathrm{S1}}$-CN protein synthesis in goats (Caroli et al., 2006).

Cebo et al. (2012) demonstrated that genetic polymorphisms at the $\alpha_{\mathrm{S}_{1}} \mathrm{CN}$ locus affect both structure and composition of milk fat globules. At mid lactation, goats displaying high-type $\alpha_{\mathrm{S1}^{-}} \mathrm{CN}$ genotypes produced larger fat globules and had lower levels of polar lipids in the milk fat globule membrane (MFGM) than goats with null $\alpha_{S_{1}}$ CN genotype. More work in this area should be expected in the coming years, because the authors suggested that genetic polymorphism in goats may be a tool to provide clues into lipid secretion pathways in the mammary epithelial cell (Cebo et al., 2012). Advances in metabolomics, using hyphenated GC-MS and multivariate data analysis techniques, enabled Caboni et al. (2016) to characterize low-molecular-weight polar metabolites in milk of 28 goats with different $\alpha_{\mathrm{S1}^{-}}$ CN genotypes in Italy. Upregulated compounds associated with weak genotypes included sugars and polyols, whereas upregulated compounds associated with strong genotypes included citric and aconitic acids (Caboni et al., 2016).

Characterizations of caprine $\kappa$-CN genotypes have been reported in JDS by several authors (Coll et al., 1993, 1995; Angiolillo et al., 2002; Yahyaoui et al., 2003). Coll et al. (1995) characterized the nucleotide sequence of the cDNA and the promoter region of the к-CN gene (CSN3). Angiolillo et al. (2002) characterized 3 variants of goat $\kappa-\mathrm{CN}$ (designated A, B, and C) in Spanish, French, German, and Italian goat breeds. Yahyaoui and colleagues (2003) proposed a nomenclature for the different alleles representing $\kappa$-CN variants. The full coding region of the $\kappa$-CN gene, including 2 new genetic variants, was described, along with allele distribution among 210 animals representing different European goat breeds and 23 Spanish wild goats. The technique described by Yahyaoui et al. (2003) allowed the rapid and simultaneous genotyping of all known $\kappa$-CN variants; use of such a system could enable selection of milk for various industrial applications.

\section{GROWTH IN GOAT POPULATION AND GOAT RESEARCH}

Goat milk research began to blossom in the 1970s, along with dairy goat populations in the United States. According to Leach (1980), the number of registered dairy goats in the United States increased from 3,611 in 1955 to 32,459 in 1976. Additionally, herds enrolled in the National Cooperative Dairy Herd Improvement Program (DHIP) increased from none in 1960 to 1,611 in 1978 (Leach, 1980). By 1987, approximately 129,225 milk goats were counted (on 15,443 farms) in the USDA Animal and Plant Health Inspection Service (APHIS) census, with approximately 17 million kilograms of milk produced; however, it was acknowledged that the census does not always capture all animals (USDAAPHIS-CEI, 2003). Considering the number of dairy goats not on test in the United States, Haenlein (1978) estimated that closer to 350 million kilograms of milk were produced by US dairy goats annually in the 1970s and 1980s. Assuming that the census captured only $60 \%$ of the true population, by 2002 , the dairy goat population had grown to 407,105 in the United States (USDA-APHIS-CEI, 2003). By 2012, the US dairy goat population was approximately 413,540 (USDA-NASS, 2012). 
It wasn't until Haenlein (1978) published "Dairy goat management" in JDS that statistically significant published research about nutritional and breeding management, behavior, and economics of milk production of dairy goats was comprehensively reported. Around this time, Larson (1978) suggested that animal scientists should be cautious in using the dairy goat as a model in lactation studies. Some of the most obvious differences, he pointed out, were the gross structural differences between goats and cows and the differing milk constituents. He also summarized the important differences in susceptibility to metabolic diseases associated with lactation and differing rates of metabolism affecting transfer of dietary and administered materials into milk.

A full issue of JDS was dedicated to dairy goats in 1980, resulting from the 1979 ADSA International Symposium on Dairy Goats (Haenlein, 1980). Issue 10 in 1980 contained 14 manuscripts related to dairy goats. Perhaps the most comprehensive summary of goat research at the time, "Composition and characteristics of goat milk: Review 1968-1979" (Jenness, 1980), was one of them. Twenty-seven (11\%) of the references cited were manuscripts published in JDS. Some of the key findings during the period from 1968 to 1979 included the observation that although fat globules of goat milk resemble those in cow milk, goat milk lacks agglutinin, which causes fat globules of cow milk to cluster when cooled (Jenness and Parkash, 1971). This, coupled with the fact that goat milk contains a higher proportion of small fat globules than large (Schultz and Chandler, 1921; Jenness 1980), explains why goat milk is called "naturally homogenized." However, it was not until Cerbulis et al. (1982) that the lipid distribution of goat milk was formally investigated and reported. Goat milk fat resembled cow milk fat with respect to lipid fractions of whole milk and cream, containing 97 to $99 \%$ free lipid (97\% of which was in the form of triglycerides) and 1 to $3 \%$ bound lipid (containing neutral lipid, glycolipid, and phospholipid). However, goat skim milk contained more free lipid than cow milk, likely because of the higher proportion of small globules (Cerbulis et al., 1982).

In the same issue as Jenness (1980), Lowenstein et al. (1980) published a review of research on goat milk products that referenced 136 publications pertaining to preparation of consumer products from goat milk; an additional 183 papers were included in a supplementary bibliography. Through their review, they concluded that, until that date, cheese was the only extensively studied goat milk product, and additional research of goat milk products is needed. Perhaps partially in response, characterizations of goat milk flavors surged in JDS in the 1980s and 1990s (Chilliard et al., 1984; Iverson and Sheppard, 1989; Ha and Lindsay, 1991; MartínezHernández et al., 1992; Jin and Park, 1995; Attaie and Richter, 1996a,b). The characteristic "goaty" aroma of goat milk products results from the VFA that are found in higher quantities in goat milk and milk products compared with cow milk. Branched-chain FA, including 4-ethylocatanoic (goat-like or "goaty") and 4-methyloctanoic (mutton-like) acids, from goat and sheep milks provide distinguishing flavors to varietal cheeses (Ha and Lindsay, 1991). Ha and Lindsay (1991) reported an absence of 4-ethylocatanoic acid in cow milk cheeses, and suggested that the flavor compound, in particular, distinguished cow from goat and sheep cheeses. Additionally, the presence of phenols, particularly $p$-cresol and 3- and 4-ethylphenols (sheep-like flavors), was unique to sheep cheeses (Ha and Lindsay, 1991). Attaie and Richter (1996a) demonstrated that ripening time significantly affected the concentrations of FFA in Cheddar-like hard goat cheeses up to $12 \mathrm{wk}$, and that the percentage of $\mathrm{NaCl}$ or the ratio of salt to moisture (S/M) did not affect FFA or lipolysis. In their companion paper (Attaie and Richter, 1996b), it was shown that firmness of the Cheddar-like cheeses decreased up to $18 \mathrm{wk}$ but no significant change occurred between wk 18 and 24. Cheeses with higher salt (highest S/M) remained the firmest, explained by the lower hydration of the protein and less freedom of movement for the protein molecules, larger amount of intact casein, and firmer casein matrix (Attaie and Richter, 1996b).

With the growing importance of dairy goats came the need for designed breeding programs. Iloeje et al. (1981) were among the first. They evaluated 21,845 records of dairy goats on Dairy Herd Improvement tests from 1965 to 1976 . The relative importance of herd (22-31\% of total variation in milk and fat yields and 15 to $25 \%$ of variation in fat \%), doe (16 to $25 \%$ or total variation in milk yield, fat yield, and fat $\%$ ), sire (8 to $10 \%$ of the total variation), and year-season effects ( 8 to $14 \%$ of total variation) were found to be similar to those for dairy cattle. Ali et al. (1983) followed up with a study of 42,618 records of goats with $125 \mathrm{~d}$ or more in milk, to examine relationships among lactation and reproduction traits. Milk and fat yields were affected by breed, parity, age after fitting parity, and month of conception. The authors recommended a reduction in the number of days dry because it was negatively correlated with milk and fat yields in subsequent lactation (Ali et al., 1983).

\section{DECADES OF ADULTERATION DETECTION}

As the appreciation for and value of goat milk increased, methods to detect goat milk adulterated with cow milk became necessary. Methods were published in 
Bulgaria (1929), Norway (1952), and France (1959) before any methods were published in the United States. Aschaffenburg and Dance (1968) were among the first to publish methods to detect cow milk in goat milk by gel electrophoresis. Furtado (1983) utilized discontinuous PAGE for detection of cow milk in pasteurized goat milk. Because of the naturally lower amount of $\alpha_{\mathrm{S} 1}-\mathrm{CN}$ in goat milk than cow milk, a frontal band, missing from the pattern of genuine goat milk and possessing the same electrophoretic mobility as bovine $\alpha_{\mathrm{S} 1}$-CN, could be directly related to the amount of cow milk added to the goat milk. Iverson and Sheppard (1989) demonstrated that adulteration of sheep and goat cheeses was occurring throughout the world by evaluating the fatty acid profiles of 134 cheeses using programmed temperature GLC of fatty acid butyl esters. Goat and sheep milk cheeses exhibited a characteristically different lower-chain-length fatty acid pattern than cow milk cheeses. The mean lauric: capric fatty acid $\left(\mathrm{C}_{12}: \mathrm{C}_{10}\right)$ ratio became proportionally larger with increased substitution of cow milk for goat or sheep milk in cheese making. Later, Molina et al. (1996) reported on the use of Western blotting of native and denatured bovine $\beta$-LG to detect addition of bovine milk to nonbovine milk cheeses. Native PAGE of whey or isoelectric focusing of $\beta$-LG isolated from the casein fractions was followed by immunodetection with anti-bovine $\beta$-LG antiserum. Immunoblotting of the native-PAGE plates of whey proteins from cheese allowed detection of heat-denatured whey proteins or pasteurized cow milk added to goat cheese at less than $1 \%$ adulteration. Even more recently, López-Calleja et al. (2004) used species-specific PCR techniques to detect sheep and goat milk adulteration with cow milk. The use of a forward primer complementary to a conserved DNA sequence, along with a reverse primer specific for cow, yielded a 223-bp fragment from cow milk DNA, whereas no amplification signal was obtained from sheep or goat milk DNA. When applied to raw, pasteurized, or sterilized milk mixtures of cow-sheep and cow-goat, the specific detection of cow milk had a good sensitivity threshold $(0.1 \%)$. In follow-up work, López-Calleja et al. (2005) validated the effectiveness of the technique to authenticate the purity of sheep milk, with similar sensitivity threshold $(0.1 \%)$. Adulteration continues to be of concern today. In Brazil, a study was requested by an association of smallholder producers to investigate and inhibit adulteration practices (Rodrígues et al., 2012). A duplex PCR assay was developed, standardized, and validated on 160 fresh bulk goat milk samples. The detection limit was $0.5 \%$ bovine milk in goat milk; $41.2 \%$ of the goat milk present in the market was adulterated with bovine milk at the time (Rodrígues et al., 2012). Also using PCR,
Golinelli et al. (2014) reported that all locally produced goat cheeses tested (20 lots of 4 brands in Brazil) were adulterated with cow milk, even though labels did not indicate addition of cow milk. Additionally, almost half of the 102 regular consumers invited to participate in triangle tests were able to perceive adulteration of goat cheese with $10 \%$ (vol/vol) cow milk (Golinelli et al., 2014). Chen et al. (2016) used proteomics to quantify the percentage of cow milk added to goat or sheep milks or dairy products. Signature tryptic peptides in $\beta$-LG were used as markers. The ultra-performance liquid chromatography triple quadrupole-mass spectrometry method was found to have high accuracy, selectivity, linearity, and precision. Similar to many previous studies, adulteration was found in most of the commercial samples purchased (Chen et al., 2016).

\section{MICROBIOLOGY AND SAFETY}

In the early part of the 20th century, livestock in the United States were commonly infected with Brucella species. Although cows were often carriers of Brucella abortus, goats carried Brucella melitensis. These were the early days of determining the current US Food and Drug Administration's "60-day rule," stating that cheesemakers must use pasteurized milk or age raw milk cheese for at least $60 \mathrm{~d}$ at not less than $35^{\circ} \mathrm{F}\left(1.5^{\circ} \mathrm{C}\right)$, which was established in 1950 (21CFR133; USDADHHS-PHS-FDA, 2016). Gilman et al. (1946) evaluated the length of time that $B$. abortus (the cow-borne source of brucellosis) survived in Cheddar cheese. Uniquely, they also evaluated the survival of $B$. melitensis (the goat-borne source of brucellosis) in goat cheeses, as fresh goat cheeses made from unpasteurized milk had been implicated in human undulant fever cases (Gilman et al., 1946). However, no documentation of cases was provided in that report. Gilman et al. (1946) also reported, similar to other work of the time, that aging for about $60 \mathrm{~d}$ would provide "reasonable assurance of the absence of viable B. abortus in commercial Cheddar cheese." Surprisingly, although Gilman and colleagues did not conduct experiments with B. melitensis, based upon previous research, they reported that B. melitensis might survive longer than $60 \mathrm{~d}$ in cheese, stating, "goat milk cheese presents a special problem." Between 1965 and 1983, outbreaks of brucellosis in Colorado and Texas were linked to consumption of cheeses made from unpasteurized goat milk sourced from the United States or Mexico, or to cheeses consumed while US residents were visiting the Mediterranean basin, Far East, Middle East, or South America (Eckman, 1975; Young and Suvannoparrat, 1975; CDC, 1983). Because of vaccination programs and vigilance, Brucella species have essentially been eradicated from US livestock since 
the 1980s. There has only been one case of B. melitensis (not $B$. abortus) reported since then - in a single cow in Texas in 1999 (USDA-APHIS-CEI, 1999).

Milk-borne infections were more common before pasteurization was discovered in the late 19th century and commonly implemented in the 20th century, but outbreaks related to consumption of unpasteurized milk remain a concern (Langer et al., 2012). In Scotland, but not England or Wales, milk pasteurization has been mandated since 1983, and sale of unpasteurized sheep or goat milk was not prohibited anywhere in Great Britain at the time Sharp et al. (1985) published. Nonetheless, more cases of foodborne illness were related to cow milk than goat milk during that time (Sharp et al., 1985). In the United States, Michigan was the first state to require milk pasteurization (in 1948); in 1987, interstate shipment of raw milk was prohibited by the Food and Drug Administration (Langer et al., 2012). In the period between 1993 and 2006, a disproportionate number (150 times higher incidence) of outbreaks of foodborne illness were associated with nonpasteurized than with pasteurized dairy products and in states that allow sales of raw milk (Langer et al., 2012). Between 2007 and 2012, 4 outbreaks were associated with goat milk compared with 77 outbreaks associated with cow milk (Mungai et al., 2015). Goat milk and milk products have tended to stay out of the food safety news spotlight, with a few exceptions, again, typically associated with unpasteurized products and mostly outside the United States (Bielaszewska et al., 1997; Hatchette et al., 2001; McIntyre et al., 2002; Méndez Martínez et al., 2003; Hogerwerf et al., 2011; Lai et al., 2015).

Because of their particularly high virulence and negative consequences in humans, contamination with Shiga toxin-producing Escherichia coli (STEC) and Listeria monocytogenes are of particular concern to dairy producers and processors. Until the 1990s, there was a lack of information of $L$. monocytogenes in goat milk compared with that available on cow and sheep milk. Because of the high mortality rate associated (30\%) with listeriosis, Gaya et al. (1996) evaluated incidence of Listeria spp. in caprine milk in Spain. The incidence of Listeria spp. in samples from bulk tanks of 405 farms was $4.15 \%$. Incidence peaked during autumn and winter months compared with the reported spring peak for cows. The findings confirmed the risk for Listeria contamination of cheese made of raw caprine milk. Of 796 raw milk cheeses obtained in 2006 and 2007 in Switzerland, 3.7 and $6.3 \%$, respectively, were positive for pathogenic STEC (Stephan et al., 2008). Of the 63 goat cheeses evaluated, 4 goat milk soft cheeses and 1 goat milk semihard cheese $(7.9 \%)$ were positive for STEC. The various serotypes were not enumerated in samples, so it is unknown whether levels were high enough to cause foodborne illness. Nonetheless, the authors concluded that raw milk cheeses continue to be a potential vehicle for transmission of pathogenic STEC to humans (Stephan et al., 2008).

D'Amico et al. (2008) studied the overall pathogen presence in 138 samples of cow, sheep, and goat raw milk, from 11 farmstead cheese operations in Vermont. The study targeted Staphylococcus aureus, Salmonella spp., L. monocytogenes, and Escherichia coli O157:H7. Goat milk samples had lower incidence (18.4\%) of Staph. aureus than cow $(27.4 \%$ or sheep $(85.7 \%)$ milk samples. Staphylococcus aureus was present at levels that would not lead to the risk of producing heat-stable enterotoxins $(<100,000 \mathrm{cfu} / \mathrm{mL})$; Staph. aureus is not considered a pathogen of high risk during cheesemaking due to competition from active starter culture. Escherichia coli O157:H7, Salmonella spp., and L. monocytogenes were not found in goat milk at levels that could cause foodborne infections but outbreaks from these microorganisms could still occur if conditions allow. D'Amico and colleagues (2008) concluded that because bacteria were found in very low levels in goat milk, improper storage could still facilitate pathogen growth, and some properties of raw milk cheeses could lead to the survival and growth of certain pathogens to risky levels.

Rahimi and Alian (2013) evaluated raw milk of buffaloes, cows, goats, sheep, and camels, in Iran, to test for the presence of Staph. aureus and its different enterotoxins. Twenty-two of the 200 samples tested positive for Staph. aureus, with the highest prevalence found in buffalo milk, followed in order by cow, sheep, goat, and camel milks. The ELISA technique was used to identify Staph. aureus enterotoxins; $45.6 \%$ of the samples produced an enterotoxin. Cow milk produced enterotoxin types A, B, and D; buffalo milk produced enterotoxin types $\mathrm{A}$ and $\mathrm{D}$; sheep milk produced enterotoxin types $\mathrm{A}$, and $\mathrm{C}$; and goat milk produced enterotoxin type D. The authors concluded that there is a high potential risk of staphylococcal food poisoning from drinking raw milk, especially if hygiene practices are not followed.

Of additional importance to the dairy industry are the many spoilage microorganisms that compromise the organoleptic, nutritious, and biochemical characteristics. Because of widespread occurrence and capability of these organisms to grow in pipelines, bulk tanks, and milking machines in dairy processing plants, Scatamburlo et al. (2015) characterized the proteolytic activity of Pseudomonas spp. isolated from 61 Brazilian goat milk samples from 12 farms. Pseudomonas spp. were confirmed by PCR by using a genus-specific region of 16S DNA. Mean Pseudomonas spp. counts ranged from 3.0 to $4.8 \log \mathrm{cfu} / \mathrm{mL}$, a smaller range than previously reported for cow milk (1.0 to $6.6 \mathrm{log} \mathrm{cfu} / \mathrm{mL}$; Pinto et al., 2006). The high proportion of proteolytic Pseudo- 
monas spp. found in the analysis indicates the need for greater attention to sanitation along the production and processing chain.

Goat milk cheeses $(n=75)$ were among 273 cheeses included in a landmark work presented by Trmčić et al. (2016), where it was proposed that coliform testing no longer be used to assess the safety of cheese. For decades, coliform bacteria have been used as indicator organisms for assessment of unsanitary conditions of manufacture. In fact, coliform testing in pasteurized milk was recommended by the US Public Health Service in the earliest edition of the grade "A" Pasteurized Milk Ordinance (PMO) published in 1924 (Martin et al., 2016) and the current tolerance limit for coliforms in milk is no more than $10 \mathrm{cfu} / \mathrm{mL}$ (USDA-DHHS-PHSFDA, 2015). However, coliforms are a diverse group, and some research has shown that only a fraction have been identified as factors of fecal contamination and a wider fraction is environmental (Martin et al., 2016). Milk pasteurization, low $\mathrm{pH}$, low water activity, and other cheese characteristics were found to contribute significantly to a lower prevalence of coliforms in cheese (Trmčić et al., 2016). Water activity was the only factor identified as determining the concentration at which coliforms are present in cheese. Although the prevalence of coliforms does not differ significantly in milk of cows, goats, and sheep (D'Amico et al., 2008; D'Amico and Donnelly, 2010), cheese manufactured from goat milk showed a higher risk of coliform detection (Trmčić et al., 2016). The authors proposed several reasons for higher coliform contamination or outgrowth: (1) intrinsic factors in goat milk or goat cheese (not including $\mathrm{pH}$ or water activity); (2) procedures involved in making goat cheese (not including pasteurization and cheese rind treatment); or (3) that goat cheese producers may represent small facilities with reduced resources related to food safety (Trmčić et al., 2016).

\section{INTERNATIONAL ADVANCES IN GOAT MILK PRODUCTS RESEARCH}

The value of goats was realized in many countries well before the United States recognized their importance, and Haenlein (1980) documented some of the international symposia and references in his 1980 JDS publication. At the time, few international works related to dairy goats had been published in JDS. Since then, the international importance of goat milk and milk products has not been overlooked in the journal. Fundamental goat milk research conducted by international authors has been key to advancing dairy goat science. Additionally, JDS has been a reservoir for international work of regional interest, including works documenting chemical composition and nutritive value of the milk of native goat breeds in Saudi Arabia (Sawaya et al., 1984) and regional goat cheeses in Italy, Turkey, Spain, and Portugal (Martínez-Hernández and Juárez, 1989; Fontecha et al., 1990; Martínez-Hernández et al., 1992; Freitas and Malcata, 2000; Yuceer et al., 2009; Trani et al., 2016).

Goat milk has not traditionally been used extensively for production of mozzarella or other pasta filata cheeses because the stretching process is not always successful. Italian investigators (Imm et al., 2003) were the first to investigate functionality and physico-chemical characteristics of goat milk mozzarella. Batches of cow or goat milk were standardized to $3.2 \%$ fat, pasteurized, and made into low moisture, part-skim mozzarella cheese using standard procedures (Kosikowski and Mistry, 1999). No difference was noted in meltability between caprine and bovine mozzarella. The free oil was always lower in goat milk mozzarella, which was attributed to intrinsic differences in goat cheese fat and protein matrix. The free oil formation in goat milk mozzarella was improved by aging for 3 to 4 wk, but decreased with additional storage, largely dictated by extent of proteolysis. The authors confirmed that structural degradation by proteolysis weakened the gel matrix and improved melting characteristics; proteolysis occurred more quickly in bovine than in caprine cheeses. Kosikowski and Mistry (1999) recommended additional research to better understand the contribution of fat globule size, polymorphic structure, and casein micelle structure on melting properties. Recently, Niro et al. (2014) partially substituted cow milk with goat or sheep milks to produce acceptable Caciocavallo cheese. From a sensory standpoint, cow Caciocavallo cheeses were characterized by higher scores for sweetness, elasticity, adhesiveness, and humidity (moisture). Mixed cow/ sheep cheeses had higher scores for intensity of flavor, acidic, astringent, friability, and salty attributes. In mixed cow/goat cheeses, solubility (fast melt in mouth), intensity of aroma, and bitter attributes predominated (Niro et al., 2014). Faccia et al. (2015) reported satisfactory production of Fior di latte cheeses from sheep and goat milk after methodological modifications from the standard cow Fior di latte process.

In Ethiopia, a research project was initiated in 2007 to address the increasing demand for goat milk cheese (Mestawet et al., 2013). The goat breeds, adapted to the climatic conditions of Ethiopia, had high casein content and good milk coagulating properties. The new mutation in the $\alpha_{S_{1}-} \mathrm{CN}$ gene that they identified, which yielded milk with very high $\alpha_{\mathrm{S1}^{-}} \mathrm{CN}$, may provide opportunities for genetic improvements (Mestawet et al., 2013). Because of interest in intensive dairy goat production and value-added goat milk products in Brazil, Fonseca et al. (2013) evaluated the influence of 
lipolytic bacteria in raw goat milk upon goat milk powder during storage. Although lipolytic psychrotrophs did not increase during $5 \mathrm{~d}$ of raw milk storage, and psychrotrophs were killed by pasteurization, peroxide value, $\mathrm{C}_{8}$ and $\mathrm{C}_{10} \mathrm{FA}$ concentrations, and total $\mathrm{FFA}$ content of milk powder increased and rancid flavors increased during $180 \mathrm{~d}$ of powder storage. Fonseca et al. (2013) concluded that raw goat milk intended for powder should be processed within $3 \mathrm{~d}$ of collection

In Norway, as consumption of the brown whey cheese (Brunost) has decreased, the interest in rennet- and acid-coagulated cheeses has increased (Inglingstad et al., 2014). As a result, the need for higher quality goat milk has increased in recent years. Inglingstad et al. (2014) examined the effect of 2 different types of pasture (cultivated and rangeland) and 2 different hay qualities (high and low quality) on goat milk composition and renneting properties. Milk from pastured goats was superior (higher casein and fat) to that from goats on hay, and goats on cultivated pasture had the highest yield; cultivated pasture yielded milk with higher $\alpha_{S 1}-C N$ and $\kappa$-CN (better renneting properties) compared with other treatments (Inglingstad et al., 2014). Providing additional support to the findings, Revilla et al. (2016) analyzed the antioxidant capacity of 224 cheese samples in Spain, prepared using mixtures of milk from cows, sheep, and goats, in 2 manufacturing seasons (winter and summer) and over 6 mo of ripening. Although animal species was not a significant factor correlated with total antioxidant capacity, statistically significant correlations were found between total antioxidant capacity and season of manufacturing (higher antioxidant activity in summer cheeses), time of ripening, retinol, fat and protein percentages, and some minerals $(\mathrm{K}, \mathrm{Mg}$, $\mathrm{Na}$, and P; Revilla et al., 2016).

\section{SUMMARY AND FUTURE DIRECTIONS}

As one of the earliest domesticated animals in the world, goats will always be an important part of human culture. Their compact size (compared with cows) makes them appealing from a herd management and milking standpoint. Additionally, physiological differences render unique physical characteristics to goat milk in terms of flavor profile, fat globule size, coagulation properties, and allergenicity, making goat milk the dairy product of choice for many consumers. Economic demand for goat milk and milk products, based on the differences between goat and cow milk and milk products, has advanced methods to detect adulteration across the globe. It is expected that such work will continue.

Although the track record of safety of goat milk and milk products is good, research must be continued to ensure the safety and quality of these products, particularly with the emergence of new foodborne pathogens and spoilage microorganisms. When Casper et al. (1998) first looked at seasonal changes in goat whey and promoted food industry applications of goat whey, "sustainability" was not yet a buzzword. But now, and into the future, additional research into methods to sustainably feed goats, responsibly improve productivity, ecologically manage effluents, and creatively utilize goat whey will be essential in management of the global dairy industry.

\section{REFERENCES}

Albenzio, M., A. Santillo, A. L. Kelly, M. Caroprese, R. Marino, and A. Sevi. 2015. Activities of indigenous proteolytic enzymes in caprine milk of different somatic cell counts. J. Dairy Sci. 98:7587-7594.

Alderson, A., and E. J. Pollak. 1980. Age-season adjustment factors for milk and fat of dairy goats. J. Dairy Sci. 63:148-151.

Ali, A. K. A., W. A. Mohammad, M. Grossman, R. D. Shanks, and G. R. Wiggans. 1983. Relationships among lactation and reproduction traits of dairy goats. J. Dairy Sci. 66:1926-1936.

Ambrosoli, R., L. Di Stasio, and P. Mazzocco. 1988. Content of $\alpha_{\mathrm{S}^{-}}$ casein and coagulation properties in goat milk. J. Dairy Sci. 71:2428.

Angiolillo, A., M. H. Yahyaoui, A. Sánchez, F. Pilla, and J. M. Folch. 2002. Characterization of a new genetic variant in the caprine к-casein gene. J. Dairy Sci. 85:2679-2680.

Aschaffenburg, R., and J. E. Dance. 1968. Detection of cow's milk in goat's milk by gel electrophoresis. J. Dairy Res. 35:383-384.

Attaie, R., and R. L. Richter. 1996a. Formation of volatile free fatty acids during ripening of Cheddar-like goat cheese. J. Dairy Sci. 79:717-724.

Attaie, R., and R. L. Richter. 1996b. Manufacturing factors and rheological characteristics of Cheddar-like goat cheese. J. Dairy Sci. 79:1-7.

Attaie, R., R. L. Richter, and A. H. Reine. 1993. Low molecular weight branched-chain and n-chain fatty acids in caprine and bovine colostrum. J. Dairy Sci. 76:62-69.

Badaoui, B., J. M. Serradilla, A. Tomás, B. Urrutia, J. L. Ares, J. Carrizosa, A. Sánchez, J. Jordana, and M. Amills. 2007. Short communication: Identification of two polymorphisms in the goat lipoprotein lipase gene and their association with milk production traits. J. Dairy Sci. 90:3012-3017.

Baldi, A., G. Savoini, F. Cheli, F. Fantuz, E. Senatore, L. Bertocchi, and I. Politis. 1996. Changes in plasmin-plasminogen-plasminogen activator in milk from Italian dairy cows. Int. Dairy J. 6:10451053.

Ballabio, C., S. Chessa, D. Rignanese, C. Gigliotti, G. Pagnacco, L. Terracciano, A. Fiocchi, P. Restani, and A. M. Caroli. 2011. Goat milk allergenicity as a function of $\alpha_{\mathrm{s} 1}$-casein genetic polymorphism. J. Dairy Sci. 94:998-1004.

Basnet, S., M. Schneider, A. Gazit, G. Mander, and A. Doctor. 2010. Fresh goat's milk for infants: Myths and realities. Pediatrics 125:e973-e977.

Bender, R. C., and L. A. Maynard. 1932. Fat metabolism in the lactating goat. J. Dairy Sci. 15:242-253.

Bergman, A. J., and C. W. Turner. 1937. The composition of the colostrum of the dairy goat. J. Dairy Sci. 20:37-45.

Bielaszewska, M., J. Janda, K. Bláhová, H. Minaříková, E. Júková, M. A. Karmali, J. Laubová, J. Sikulová, M. A. Preston, R. Khakhria, H. Karch, H. Klazarová, and O. Nyč. 1997. Human Escherichia coli O157:HT7 infection associated with the consumption of unpasteurized goat's milk. Epidemiol. Infect. 119:299-305.

Bitting, A. W. 1902. The physiology of milk secretion. Bureau of Animal Industry, U.S. Dept. Agric., 19th Ann. Rep. 254-273.

Blackham, R. J. 1906. Goats' milk for infants. Lancet 168:895-896. 
Bosworth, A. W., and L. L. Van Slyke. 1916a. A comparison of the composition of cow's milk, goat's milk, and human milk. J. Biol. Chem. 24:177-185.

Bosworth, A. W., and L. L. Van Slyke. 1916b. The casein of goat's milk. J. Biol. Chem. 24:173-175.

Bosworth, A. W., and L. L. Van Slyke. 1916c. The soluble and insoluble compounds of goat's milk. J. Biol. Chem. 24:187-189.

Bouattour, M. A., R. Casals, E. Albanell, X. Such, and G. Caja. 2008. Feeding soybean oil to dairy goats increases conjugated linoleic acid in milk. J. Dairy Sci. 91:2399-2407.

Breckenridge, W. C., and A. Kuksis. 1967. Molecular weight distributions of milk fat triglycerides from seven species. J. Lipid Res. 8:473-478.

Brundige, D. R., E. A. Maga, K. C. Klasing, and J. D. Murray. 2008. Lysozyme transgenic goats' milk influences gastrointestinal morphology in young pigs. J. Nutr. 138:921-926.

Caboni, P., A. Murgi, A. Porcu, M. Drmuru, G. Pulina, and A. Nudda. 2016. Gas chromatography-mass spectrometry metabolomics of goat milk with different polymorphism at the $\alpha_{\mathrm{s} 1}$-casein genotype locus. J. Dairy Sci. 99:6046-6051.

Cahill, J. 1906. Goat's milk for infants. Lancet 168:954-955.

Cais-Sokolińska, D., J. Wójtowski, J. Pikul, R. Danków, M. Majcher, J. Teichert, and E. Bagnicka. 2015. Formation of volatile compounds in kefir made of goat and sheep milk with high polyunsaturated fatty acid content. J. Dairy Sci. 98:6692-6705.

Caroli, A., F. Chiatti, S. Chessa, D. Rignanese, P. Bolla, and G. Pagnacco. 2006. Focusing on the goat casein complex. J. Dairy Sci 89:3178-3187.

Casper, J. L., W. L. Wendorff, and D. L. Thomas. 1998. Seasonal changes in protein composition of whey from commercial manufacture of caprine and ovine specialty cheeses. J. Dairy Sci. 81:31173122 .

CDC (Centers for Disease Control and Prevention). 1983. Epidemiologic notes and reports Brucellosis - Texas. Mobidity and Mortality Weekly Report. Accessed May 28, 2017. https://www.cdc.gov/ $\mathrm{mmwr} /$ preview/mmwrhtml/00000163.htm.

Cebo, C., C. López, C. Henry, C. Beauvallet, O. Ménard, C. Bevilacqua, F. Bouvier, H. Caillat, and P. Martin. 2012. Goat $\alpha_{\mathrm{s} 1}$-casein genotype affects milk fat globule physicochemical properties and the composition of the milk fat globule membrane. J. Dairy Sci. 95:6215-6229.

Cerbulis, J., O. W. Parks, and H. M. Farrell Jr.. 1982. Composition and distribution of lipids of goats' milk. J. Dairy Sci. 65:2301-2307.

Chandan, R. C., R. M. Parry, and K. M. Shahani. 1968. Lysozyme, lipase and ribonuclease in milk of various species. J. Dairy Sci. 51:606-607.

Chandan, R. C., K. M. Shahani, and R. G. Holly. 1964. Lysozyme content of human milk. Nature 204:76.

Chen, Q., X. Ke, J. S. Zhang, S. Y. Lai, F. Fang, W. M. Mo, and Y. P. Ren. 2016. Proteomics method to quantify the percentage of cow, goat, and sheep milks in raw materials for dairy products. J. Dairy Sci. 99:9483-9492.

Chen, S. X., M. Rovai, A. L. Lock, D. E. Bauman, T. A. Gipson, F. Z. Ren, and S. S. Zeng. 2009. Short communication: Effects of milk fat depression induced by a dietary supplement containing trans-10, cis-12 conjugated linoleic acid on properties of semi-hard goat cheese. J. Dairy Sci. 92:2534-2538.

Chen, S. X., J. Z. Wang, J. S. Van Kessel, F. Z. Ren, and S. S. Zeng. 2010. Effect of somatic cell count in goat milk on yield, sensory quality, and fatty acid profile of semisoft cheese. J. Dairy Sci. 93:1345-1354.

Chilliard, Y., A. Ferlay, J. Rouel, and G. Lamberet. 2003. A review of nutritional and physiological factors affecting goat milk lipid synthesis and lipolysis. J. Dairy Sci. 86:1751-1770.

Chilliard, Y., G. Selselet-Attou, P. Bas, and P. Morand-Fehr. 1984. Characteristics of lipolytic system in goat milk. J. Dairy Sci 67:2216-2223.

Clark, S., and J. W. Sherbon. 2000. Genetic variants of alpha ${ }_{\mathrm{S}_{1}}{ }^{-} \mathrm{CN}$ in goat milk: Breed distribution and associations with milk composition and coagulation properties. Small Rumin. Res. 38:135-143.
Coll, A., J. M. Folch, and A. Sánchez. 1993. Nucleotide sequence of the goat $\kappa$-casein cDNA. J. Anim. Sci. 71:2833.

Coll, A., J. M. Folch, and A. Sánchez. 1995. Structural features of the $5^{\prime}$ flanking region of the caprine $\mathrm{k}$-casein gene. J. Dairy Sci. 78:973-977.

Collins, R. A., R. E. Boldt, C. A. Elvehjem, and E. B. Hart. 1953b. The influence of trace-mineralized salt upon the vitamin B12 and folic acid content of goat's milk. J. Dairy Sci. 36:29-32.

Collins, R. A., R. E. Boldt, C. A. Elvehjem, E. B. Hart, and R. A Bomstein. 1953a. Further studies on the folic acid and vitamin B12 content of cow's milk. J. Dairy Sci. 36:24-28.

Collins, R. A., A. E. Harper, M. Schreiber, and C. A. Elvehjem. 1951. The folic acid and vitamin $\mathrm{B}_{12}$ content of the milk of various species. J. Nutr. 43:313-321.

Contreras, A., J. C. Corrales, A. Sánchez, and D. Sierra. 1997. Persistence of subclinical intramammary pathogens in goats throughout lactation. J. Dairy Sci. 80:2815-2819.

Contreras, A., C. Luengo, A. Sánchez, and J. C. Corrales. 2003. The role of intramammary pathogens in dairy goats. Livest. Prod. Sci. 79:273-283.

Cunningham, O. C., and L. H. Addington. 1936. The effect of early breeding upon the milk energy production of grade and purebred Toggenburg goats. J. Dairy Sci. 19:405-409.

D'Amico, D. J., and C. W. Donnelly. 2010. Microbiological quality of raw milk used for small-scale artisan cheese production in Vermont: Effect of farm characteristics and practices. J. Dairy Sci. 93:134-147.

D'Amico, D. J., E. Groves, and C. W. Donnelly. 2008. Low incidence of foodborne pathogens of concern in raw milk utilized for farmstead cheese production. J. Food Prot. 71:1580-1589.

Dalebrook, J. 1902. Feeding on goat's milk. Lancet 159:334.

Davidson, G. P., and R. R. W. Townley. 1977. Structural and functional abnormalities of the small intestine due to nutritional folic acid deficiency in infancy. J. Pediatr. 90:590-594.

DeFeo, A. A., P. S. Dimick, and A. Kilara. 1982. Purification and partial characterization of caprine milk lipoprotein lipase. J. Dairy Sci. 65:2308-2316.

Dimick, P. S., and S. Patton. 1965. Structure and synthesis of milk fat. VII. Distribution of fatty acids in milk fat triglycerides with special reference to butyrate. J. Dairy Sci. 48:444-449.

Dulin, A. M., M. J. Paape, and W. P. Wergin. 1982. Differentiation and enumeration of somatic cells in goat milk. J. Food Prot. 45:435-439.

Dulin, A. M. M., J. Paape, W. D. Schultze, and B. T. Weinland. 1983. Effect of parity, stage of lactation, and intramammary infection on concentration of somatic cells and cytoplasmic particles in goat milk. J. Dairy Sci. 66:2426-2433.

Eckman, M. R. 1975. Brucellosis linked to Mexican cheese. JAMA 232:636-637.

Edmunds, W. 1914. Goats' milk. Lancet 183:422. https://doi.org/10 .1016/S0140-6736(00)53197-3.

Efthymiou, C. C., and J. F. Mattick. 1964. Development of domestic feta cheese. J. Dairy Sci. 47:593-598.

Elvehjem, C. A. 1953. What is new in the nutritive value of milk. J. Dairy Sci. 36:1264-1266.

Faccia, M., A. Trani, G. Gambacorta, P. Loizzo, A. Cassone, and F. Caponio. 2015. Production technology and characterization of Fior di latte cheeses made from sheep and goat milks. J. Dairy Sci. 98:1402-1410.

Fantuz, F., F. Polidori, F. Cheli, and A. Baldi. 2001. Plasminogen activation system in goat milk and its relation with composition and coagulation properties. J. Dairy Sci. 84:1786-1790.

Farlow, D. W., X. Su, and T. D. Veenstra. 2009. Quantitative measurement of endogenous estrogen metabolites, risk-factors for development of breast cancer, in commercial milk products by LCMS/MS. J. Chromatogr. B Analyt. Technol. Biomed. Life Sci. 877:1327-1334.

Farlow, D. W., X. Su, and T. D. Veenstra. 2012. Comparison of estrone and $17 \beta$-estradiol levels in commercial goat and cow milk. J. Dairy Sci. 95:1699-1708. 
Fonseca, C. R., K. Bordin, A. M. Fernándes, C. E. C. Rodrígues, C H. Corrassin, A. G. Cruz, and C. A. F. Oliveira. 2013. Storage of refrigerated raw goat milk affecting the quality of whole milk powder. J. Dairy Sci. 96:4716-4724.

Fontecha, J., C. Peláez, M. Juárez, T. Requena, and C. Gómez. 1990. Biochemical and microbiological characteristics of artisanal hard goat's cheese. J. Dairy Sci. 73:1150-1157.

Ford, J. E., and K. J. Scott. 1968. The folic acid activity of some milk foods for babies. J. Dairy Res. 35:85-90.

Freeman, C. P., E. L. Jack, and L. M. Smith. 1965. Intramolecular fatty acid distribution in the milk fat triglycerides of several species. J. Dairy Sci. 48:853-858.

Freitas, C., and F. X. Malcata. 2000. Microbiology and biochemistry of cheeses with Appelation d'Origine Protegee and manufactured in the Iberian Peninsula from ovine and caprine milks. J. Dairy Sci. 83:584-602.

Furtado, M. M. 1983. Detection of cow milk in goat milk by polyacrylamide gel electrophoresis. J. Dairy Sci. 66:1822-1824.

Gaya, P., C. Saralegui, M. Medina, and M. Núñez. 1996. Occurrence of Listeria monocytogenes and other Listeria spp. in raw caprine milk. J. Dairy Sci. 79:1936-1941.

Gelasakis, A. I., A. S. Angelidis, R. Giannakou, G. Filloussis, M. S. Kalamaki, and G. Arsenos. 2016. Bacterial subclinical mastitis and its effect on milk yield in low-input dairy goat herds. J. Dairy Sci. 99:3698-3708.

Gilman, H. L., A. C. Dahlberg, and J. C. Marquardt. 1946. The occurrence and survival of Brucella abortis in Cheddar and Limburger cheese. J. Dairy Sci. 29:71-85.

Golinelli, L. P., A. C. Carvalho, R. S. Casaes, C. S. C. Lopes, R Deliza, V. M. F. Paschoalin, and J. T. Silva. 2014. Sensory analysis and species-specific PCR detect bovine milk adulteration of frescal (fresh) goat cheese. J. Dairy Sci. 97:6693-6699.

Guo, M. R., P. H. Dixon, Y. W. Park, J. A. Gilmore, and P. S. Kindstedt. 2001. Seasonal changes in the chemical composition of commingled goat milk. J. Dairy Sci. 84(E. Suppl.):E79-E83.

Ha, J. K., and R. C. Lindsay. 1991. Contributions of cow, sheep, and goat milks to characterizing branched chain fatty acid and phenolic flavors in varietal cheeses. J. Dairy Sci. 74:3274.

Haenlein, G. F. W. 1978. Dairy goat management. J. Dairy Sci. 61:1011-1022.

Haenlein, G. F. W. 1980. Status of world literature on dairy goats, introductory remarks. J. Dairy Sci. 63:1591-1599.

Haenlein, G. F. W. 1981. Dairy Goat Industry of the United States. J. Dairy Sci. 64:1288-1304.

Haenlein, G. F. W. 2001. Past, present, and future perspectives of small ruminant dairy research. J. Dairy Sci. 84:2097-2115.

Harper, A. E., R. M. Richard, and R. A. Collins. 1951. The influence of dietary cobalt upon the vitamin $\mathrm{B}_{12}$ content of ewe's milk. Arch. Biochem. Biophys. 31:328-329.

Hatchette, T. F., R. C. Hudson, W. F. Schlech, N. A. Campbell, J. E. Hatchette, S. Ratnam, D. Raoult, C. Donovan, and T. J. Marrie. 2001. Goat-associated Q Fever: A new disease in Newfoundland. Emerg. Infect. Dis. 7:413-419.

Hogerwerf, L., R. van den Brom, H. I. J. Roest, A. Bouma, P. Vellema, M. Pieterse, D. Dercksen, and M. Nielen. 2011. Reduction of Coxiella burnetii prevalence by vaccination of goats and sheep, the Netherlands. Emerg. Infect. Dis. 17:379-386.

Høst, A. 2002. Frequency of cow's milk allergy in childhood. Ann. Allergy Asthma Immunol. 89(Suppl 1):33-37.

Iloeje, M. U., L. D. Van Vleck, and G. R. Wiggans. 1981. Components of variance for milk and fat yields in dairy goats. J. Dairy Sci. 64:2290-2293.

Imm, J. Y., E. J. Oh, K. S. Han, S. Oh, Y. W. Park, and S. H. Kim. 2003. Functionality and physico-chemical characteristics of bovine and caprine mozzarella cheeses during refrigerated storage. J. Dairy Sci. 86:2790-2798.

Inglingstad, R. A., H. Steinshamn, B. S. Dagnachew, B. Valenti, A. Criscione, E. O. Rukke, T. G. Devold, S. B. Skeie, and G. E. Vegarud. 2014. Grazing season and forage type influence goat milk composition and rennet coagulation properties. J. Dairy Sci. 97:3800-3814.
Iverson, J. L., and A. J. Sheppard. 1989. Detection of adulteration in cow, goat, and sheep cheeses utilizing gas-liquid chromatographic fatty acid data. J. Dairy Sci. 72:1707-1712.

Jack, E. L., C. P. Freeman, L. M. Smith, and J. B. Kickle. 1963. Pancreatic lipase Hydrolysis of cow milk fat. J. Dairy Sci. 46:284.

Jenness, R. 1980. Composition and characteristics of goat milk: Review 1968-1979. J. Dairy Sci. 63:1605-1630.

Jenness, R., and S. Parkash. 1971. Lack of a fat globule clustering agent in goats' milk. J. Dairy Sci. 54:123-126.

Jensen, R. G., J. Sampugna, and G. W. Gander. 1961. Fatty acid composition of the diglycerides from lipolyzed milk fat. J. Dairy Sci. 44:1983

Jin, Y. K., and Y. W. Park. 1995. Effects of aging time and temperature on proteolysis of commercial goat milk cheeses produced in the United States. J. Dairy Sci. 78:2598-2608.

Kaba, J., N. Strzałkowska, A. Jóźwik, J. Krzyżewski, and E. Bagnicka. 2012. Twelve-year cohort study on the influence of caprine arthritis-encephalitis virus infection on milk yield and composition. J. Dairy Sci. 95:1617-1622

Koop, G. S. De Vliegher, A. De Visscher, K. Supré, F. Haesebrouck, M. Nielen, and T. van Werven. 2012. Differences between coagulase-negative Staphylococcus species in persistence and in effect on somatic cell count and milk yield in dairy goats. J. Dairy Sci. 95:5075-5084.

Koop, G., T. van Werven, H. J. Schuiling, and M. Nielen. 2010. The effect of subclinical mastitis on milk yield in dairy goats. J. Dairy Sci. 93:5809-5817.

Kosikowski, F. V., and V. V. Mistry. 1999. Soft Italian cheese-Mozzarella and ricotta. Pages 174-193 in Cheese and Fermented Milk Foods. Vol. I: Origins and Principles. 3rd ed. F. V. Kosikowski, ed. F. V. Kosikowski LLC, Great Falls, VA.

Lai, C.-H., L.-L. Chang, J.-N. Lin, M.-H. Liao, S.-S. Liu, H.-H. Lee, H.-H. Lin, and Y.-H. Chen. 2015. Association of human Q fever with animal husbandry, Taiwan, 2004-2012. Emerg. Infect. Dis. $21: 2217-2220$.

Langer, A. J., T. Ayers, J. Grass, M. Lynch, F. J. Angulo, and B. E. Mahon. 2012. Nonpasteurized dairy products, disease outbreaks, and state laws-United States, 1993-2006. Emerg. Infect. Dis. 18:385-391.

Larson, B. L. 1978. The dairy goat as a model in lactation studies. J. Dairy Sci. 61:1023-1029.

Leach, K. 1980. Trends in dairy goats. J. Dairy Sci. 63:1600-1604.

Lisson, M., N. Novak, and G. Erhardt. 2014. Immunoglobulin E epitope mapping by microarray immunoassay reveals differences in immune response to genetic variants of caseins from different ruminant species. J. Dairy Sci. 97:1939-1954.

López-Calleja, I., I. González, V. Fajardo, M. A. Rodríguez, P. E. Hernández, T. García, and R. Martín. 2004. Rapid detection of cows' milk in sheeps' and goats' milk by a species-specific polymerase chain reaction technique. J. Dairy Sci. 87:2839-2845.

López-Calleja, I., I. González, V. Fajardo, M. A. Rodríguez, P. E. Hernández, T. García, and R. Martín. 2005. Application of polymerase chain reaction to detect adulteration of sheep's milk with goats' milk. J. Dairy Sci. 88:3115-3120.

Lowenstein, M., S. J. Speck, H. M. Barnhart, and J. F. Frank. 1980. Research on goat milk products: A review. J. Dairy Sci. 63:16311648.

Luna, P., A. Bach, M. Juárez, and M. A. de la Fuente. 2008. Effect of a diet enriched in whole linseed and sunflower oil on goat milk fatty acid composition and conjugated linoleic acid isomer profile. J. Dairy Sci. 91:20-28.

Lythgoe, H. C. 1940. Composition of goat milk of known purity. J. Dairy Sci. 23:1097-1108.

Maga, E. A., J. S. Cullor, W. Smith, G. B. Anderson, and J. D. Murray. 2006a. Human lysozyme expressed in the mammary gland of transgenic dairy goats can inhibit the growth of bacteria that cause mastitis and the cold-spoilage of milk. Foodborne Pathog. Dis. 3:384-392.

Maga, E. A., C. F. Shoemaker, J. D. Rowe, R. H. BonDurant, G. B. Anderson, and J. D. Murray. 2006b. Production and processing 
of milk from transgenic goats expressing human lysozyme in the mammary gland. J. Dairy Sci. 89:518-524.

Martin, N. H., A. Trmčić, T.-H. Hsieh, K. J. Boor, and M. Wiedmann. 2016. The evolving role of coliforms as indicators of unhygienic processing conditions in dairy foods. Front. Microbiol. 7:1549.

Martin, P., and P. Addeo. 1996. Genetic polymorphism of casein in the milk of goats and sheep. Pages 45-58 in Production and Utilization of Ewe and Goat Milk; Proc. IDF/Greek National Committee of IDF/CIRVAL Seminar, Crete, Greece.

Martínez-Hernández, M. C., and M. Juárez. 1989. Retention of main and trace elements in four types of goat cheese. J. Dairy Sci. 72:1092-1097.

Martínez-Hernández, M. C., M. Juárez, and M. Ramos. 1992. Biochemical characteristics of three types of goat cheese. J. Dairy Sci. 75:1747-1752.

Martínez Marín, A. L., P. Gómez-Cortés, G. Gómez Castro, M. Juárez, L. Pérez Alba, M. Pérez Hernández, and M. A. de la Fuente. 2012. Effects of feeding increasing dietary levels of high oleic or regular sunflower or linseed oil on fatty acid profile of goat milk. J. Dairy Sci. 95:1942-1955.

Martínez-Navalón, B., C. Peris, E. A. Gómez, B. Peris, M. L. Roche, C. Caballero, E. Goyena, and E. Berriatua. 2013. Quantitative estimation of the impact of caprine arthritis encephalitis virus infection on milk production by dairy goats. Vet. J. 197:311-317.

McIntyre, L., J. Fung, A. Paccagnella, J. Isaac-Renton, F. Rockwell, B. Emerson, and T. Preston. 2002. Escherichia coli O157 outbreak associated with the ingestion of unpasteurized goat's milk in British Columbia, 2001. Can. Commun. Dis. Rep. 28:6-8.

Méndez Martínez, C., A. Páez Jiménez, M. Cortés-Blanco, E. Salmoral Chamizo, E. Mohedano Mohedano, C. Plata, A. Varo Baena, and F. Martínez Navarro. 2003. Brucellosis out- break due to unpasteurized raw goat cheese in Andalucía (Spain), January-March 2002. Euro Surveill. 8:164-168.

Mestawet, T. A., A. Girma, T. Adnøy, T. G. Devold, and G. E. Vegarud. 2013. Newly identified mutations at the CSN1S1 gene in Ethiopian goats affect casein content and coagulation properties of their milk. J. Dairy Sci. 96:4857-4869.

Molina, E., A. Fernández-Fournier, M. De Frutos, and M. Ramos. 1996. Western blotting of native and denatured bovine $\beta$-lactoglobulin to detect addition of bovine milk in cheese. J. Dairy Sci. 79:191-197.

Mora-Gutierrez, A., T. F. Kumosinski, and H. M. Farrell. 1991. Quantification of $\alpha_{\mathrm{s} 1}$-casein in goat milk from French-Alpine and AngloNubian breeds using reversed-phase high performance liquid chromatography. J. Dairy Sci. 74:3303-3307.

Moroni, P., G. Pisoni, C. Vimercati, M. Rinaldi, B. Castiglioni, P. Cremonesi, and P. Boettcher. 2005. Characterization of Staphylococcus aureus isolated from chronically infected dairy goats. J. Dairy Sci. 88:3500-3509.

Mungai, E. A., C. B. Behravesh, and L. H. Gould. 2015. Increased outbreaks associated with nonpasteurized milk, United States, 2007-2012. Emerg. Infect. Dis. 21:119-122.

Niro, S., A. Fratianni, P. Tremonte, E. Sorrentino, L. Tipaldi, G. Panfili, and R. Coppola. 2014. Innovative Caciocavallo cheeses made from a mixture of cow milk with ewe or goat milk. J. Dairy Sci. 97:1296-1304.

Oster, K. A. 1971. Plasmalogen diseases. A new concept of the etiology of the atherosclerotic process. Am. J. Clin. Res. 2:30-35.

Park, Y. W. 1991. Interrelationships between somatic cell counts, electrical conductivity, bacteria counts, percent fat and protein in goat milk. Small Rumin. Res. 5:367-375.

Park, Y. W. 2001. Proteolysis and lipolysis of goat milk cheese. J. Dairy Sci. 84(E. Suppl.):E84-E92.

Park, Y. W., and R. D. Humphrey. 1986. Bacterial cell counts in goat milk and their correlations with somatic cell counts, percent fat, and protein. J. Dairy Sci. 69:32-37.

Parkash, S., and R. Jenness. 1968. The composition and characteristics of goats' milk: A review. Dairy Sci. Abstr. 30:67.

Pinto, C. L. O., M. L. Martins, and M. C. D. Vanetti. 2006. Microbial quality of raw refrigerated milk and isolation of psychrotrophic proteolytic bacteria. Ciênc. Tecnol. Aliment. 26:645-651.
Politis, I., J. H. White, K. O'Hare, B. Zavizion, J. Gilmore, and W. Caler. 1994. Distribution of plasminogen activator forms in fractions of goat milk. J. Dairy Sci. 77:2900-2906.

Poutrel, B., and C. Lerondelle. 1983. Cell content of goat milk: California Mastitis Test, Coulter counter, and Fossomatic for predicting half infection. J. Dairy Sci. 66:2575-2579.

Rahimi, E., and F. Alian. 2013. Presence of enterotoxigenic Staphylococcus aureus in cow, camel, sheep, goat, buffalo bulk tank milk. Vet. Arh. 83:23-30.

Revilla, I., M. I. González-Martín, A. M. Vivar-Quintana, M. A. Blanco-López, I. A. Lobos-Ortega, and J. M. Hernández-Hierro. 2016. Antioxidant capacity of different cheeses: Affecting factors and prediction by near infrared spectroscopy. J. Dairy Sci. 99:5074-5082.

Roadhouse, C. L., and J. L. Henderson. 1950. The Market Milk Industry. 2nd ed. McGraw-Hill Book Co., New York, NY.

Rodrígues, N. P. A., P. E. N. Givisiez, R. C. R. E. Queiroga, P. S. Azevedo, W. A. Gebreyes, and C. J. B. Oliveira. 2012. Milk adulteration: Detection of bovine milk in bulk goat milk produced by smallholders in northeastern Brazil by a duplex PCR assay. J. Dairy Sci. 95:2749-2752.

Rusoff, L. L. 1955. The miracle of milk. An important message for people of all ages. J. Dairy Sci. 38:1057-1068.

Sankarlal, V. M., E. D. Testroet, D. C. Beitz, and S. Clark. 2015. Dried distillers' grains with solubles (DDGS) do not always cause late-blowing in baby Swiss cheese. J. Dairy Sci. 98:8545-8553.

Sawaya, W. N., W. J. Safi, A. F. Al-Shalhat, and M. M. Al-Mohammad. 1984. Chemical composition and nutritive value of goat milk. J. Dairy Sci. 67:1655-1659.

Scatamburlo, T. M., A. K. Yamazy, V. Q. Cavicchioli, F. A. Pieri, and L. A. Nero. 2015. Spoilage potential of Pseudomonas species isolated from goat milk. J. Dairy Sci. 98:759-764.

Schultz, E. W., and L. R. Chandler. 1921. The size of fat globules in goat's milk. J. Biol. Chem. 46:133-134.

Sharp, J. C., G. M. Paterson, and N. J. Barrett. 1985. Pasteurisation and the control of milkborne infection in Britain. Br. Med. J. (Clin. Res. Ed.) 291:463-464.

Stephan, R., S. Schumacher, S. Corti, G. Krause, J. Danuser, and L. Beutin. 2008. Prevalence and characteristics of Shiga toxinproducing Escherichia coli in Swiss raw milk cheeses collected at producer level. J. Dairy Sci. 91:2561-2565.

Testroet, E. D., G. Li, D. C. Beitz, and S. Clark. 2015. Dried distillers grains with solubles affects composition but not oxidative stability of milk. J. Dairy Sci. 98:2908-2919.

The Center for Food Security and Public Health. 2007. Pages $1-5$ in Caprine Arthritis and Encephalitis. Small Ruminants Lentivirus Infection. College of Veterinary Medicine, Iowa State University, Ames.

Timms, L. L., and L. H. Schultz. 1985. N-Acetyl-B-D-glucosaminidase activity and somatic cells in goat milk. J. Dairy Sci. 68:3363-3366.

Toral, P. G., Y. Chilliard, J. Rouel, H. Leskinen, K. J. Shingfield, and L. Bernard. 2015. Comparison of the nutritional regulation of milk fat secretion and composition in cows and goats. J. Dairy Sci. 98:7277-7297.

Trani, A., G. Gambacorta, P. Loizzo, A. Cassone, and M. Faccia 2016. Short communication: Chemical and sensory characteristics of Canestrato di Moliterno cheese manufactured in spring. J. Dairy Sci. 99:6080-6085.

Trmčić, A., K. Chauhan, D. J. Kent, R. D. Ralyea, N. H. Martin, K. J. Boor, and M. Wiedmann. 2016. Coliform detection in cheese is associated with specific cheese characteristics, but no association was found with pathogen detection. J. Dairy Sci. 99:6105-6120.

Trujillo, A. J., B. Guamis, and C. Carretero. 1997. Hydrolysis of caprine $\beta$-casein by plasmin. J. Dairy Sci. 80:2258-2263.

US DHHS-PHS-FDA (Department of Health and Human Services, Public Health Service, Food and Drug Administration). 2015. Grade "A" Pasteurized Milk Ordinance. Accessed August 24, 2017. https://www.fda.gov/downloads/food/guidanceregulation/ guidancedocumentsregulatoryinformation/milk/ucm513508.pdf.

US DHHS-PHS-FDA (Department of Health and Human Services, Public Health Service, Food and Drug Administration). 2016. 21CFR133.113 Subchapter B: Cheeses and Related Cheese Prod- 
ucts: Subpart B-Requirements for Specific Standardized Cheese and Related Products: Cheddar cheese. Accessed May 24, 2017. https://www.accessdata.fda.gov/scripts/cdrh/cfdocs/cfcfr/ CFRSearch.cfm?fr=133.113.

USDA-APHIS-CEI (USDA Animal and Plant Health Inspection Service, Center for Emerging Issues). 1999. Brucella melitensis in Texas. October 1999 Impact Worksheet. Accessed May 28, 2017. https://www.aphis.usda.gov/animal_health/emergingissues/ impactworksheets/iw_1999_files/domestic/brucellatexas_1099 .htm.

USDA-APHIS-CEI (USDA Animal and Plant Health Inspection Service, Center for Emerging Issues). 2003. The goat industry: Structure concentration, demand and growth. Accessed May 30, 2017. https://www.aphis.usda.gov/animal_health/emergingissues/ downloads/goatreport090805.pdf.

USDA-NASS (National Agricultural Statistics Service). 2012. Census of Agriculture. https://www.agcensus.usda.gov/Publications/2012/ Online_Resources/Ag_Atlas_Maps/Livestock_and_Animals/.

Van Hekken, D. L., M. H. Tunick, and Y. W. Park. 2005. Effect of frozen storage on the proteolytic and rheological properties of soft caprine milk cheese. J. Dairy Sci. 88:1966-1972.

Williams, H. H., and L. A. Maynard. 1934. The effect of specific dietary fats on the blood lipids of lactating goats. J. Dairy Sci. 17:223-232.

World Cancer Research Fund/American Institute for Cancer Research. 2007. Chapter 4: Food and drinks; 4.4. Milk and dairy products. Pages 129-132 in Food, Nutrition, Physical Activity and the Pre- vention of Cancer: A Global Perspective. American Institute for Cancer Research, Washington DC.

Wright, W. 1906. Infantile mortality and goats' milk. Lancet 168:1212 1213.

Yager, J. D., and N. Davidson. 2006. Mechanisms of disease-Estrogen carcinogenesis in breast cancer. N. Engl. J. Med. 354:270-282.

Yahyaoui, M. H., A. Angiolillo, F. Pilla, A. Sánchez, and J. M. Folch. 2003. Characterization and genotyping of the caprine $\kappa$-casein variants. J. Dairy Sci. 86:2715-2720.

Young, E. J., and U. Suvannoparrat. 1975. Brucellosis outbreak attributed to ingestion of unpasteurized goat cheese. Arch. Intern. Med. 135:240-243.

Yuceer, Y. K., B. Tuncel, O. Guneser, B. Engin, M. Isleten, K. Yasar, and M. Mendes. 2009. Characterization of aroma-active compounds, sensory properties, and proteolysis in Ezine cheese. J. Dairy Sci. 92:4146-4157.

Zeng, S. S. 1996. Comparison of goat milk standards for analyses of somatic cell count, fat and protein in goat milk. Small Rumin. Res. 21:221-225.

Zeng, S. S., and E. N. Escobar. 1996. Effect of breed and milking method on somatic cell count, standard plate count and composition of goat milk. Small Rumin. Res. 19:169-175.

Ziegler, D. S., S. J. Russell, G. Rozenberg, C. A. James, T. N. Trahair and T. A. O'Brien. 2005. Goats' milk quackery. J. Paediatr. Child Health 41:569-571.

Zikakis, J. P., and S. C. Wooters. 1980. Activity of xanthine oxidase in dairy products. J. Dairy Sci. 63:893-904.

\section{APPENDIX}

Table A1. Milestones in goat milk research in the past century

\begin{tabular}{|c|c|c|}
\hline Date & Milestone & Reference \\
\hline $1932 ; 1934$ & $\begin{array}{l}\text { First dairy goat fat metabolism papers published in Journal of Dairy } \\
\text { Science; dairy goats are used in research as surrogates for cows to save } \\
\text { expense. }\end{array}$ & $\begin{array}{l}\text { Bender and Maynard, 1932; } \\
\text { Williams and Maynard, } 1934\end{array}$ \\
\hline 1937 & First publication about composition of goat colostrum. & Bergman and Turner, 1937 \\
\hline 1940 & First proximate analysis of goat milk (355 goats from 21 herds). & Lythgoe, 1940 \\
\hline 1953 & $\begin{array}{l}\text { Companion publications investigate the impact of mineral } \\
\text { supplementation on folic acid and vitamin } B_{12} \text { in cow and goat } \\
\text { colostrum and milk. }\end{array}$ & Collins et al., 1953a,b \\
\hline 1965 & $\begin{array}{l}\text { First understanding about butyric acid and milk fat synthesis using cow } \\
\text { and goat milk. }\end{array}$ & Dimick and Patton, 1965 \\
\hline 1968 & First report of lysozyme, lipase, and ribonuclease in milk of 5 species. & Chandan et al., 1968 \\
\hline 1968 & $\begin{array}{l}\text { Evidence shows that goat milk is nutritionally similar to cow milk but } \\
\text { is an inadequate source of vitamins } B_{6}, B_{12} \text { and folic acid compared } \\
\text { with cow milk for infant nutrition. Research begins on detection of } \\
\text { adulteration of goat milk with cow milk. }\end{array}$ & $\begin{array}{l}\text { Ford and Scott, 1968; Parkash and } \\
\text { Jenness, 1968; Aschaffenburg and } \\
\text { Dance, 1968; Chandan et al., } 1968\end{array}$ \\
\hline
\end{tabular}


Table A1 (Continued). Milestones in goat milk research in the past century

\begin{tabular}{|c|c|c|}
\hline Date & Milestone & Reference \\
\hline 1971 & $\begin{array}{l}\text { Goat milk fat globules resemble those of cow milk, but with a higher } \\
\text { proportion of small fat globules, and lack agglutinin. }\end{array}$ & Jenness and Parkash, 1971 \\
\hline 1978 & $\begin{array}{l}\text { Caution is suggested in the use of goats as a model species in lactation } \\
\text { studies due to significant differences from cows. }\end{array}$ & Larson, 1978 \\
\hline 1980 & $\begin{array}{l}\text { First report indicating that the } 5 \text { principal proteins in goat milk ( } \alpha_{\mathrm{S1}^{-}} \\
\text {casein, } \alpha_{\mathrm{S2}} \text {-casein, } \beta \text {-casein, } \beta \text {-lactoglobulin, and } \alpha \text {-lactalbumin) closely } \\
\text { resemble the cow milk proteins; } \alpha_{\mathrm{S} 1^{-} \text {-casein is suggested to play a role in }} \\
\text { milk allergenicity. }\end{array}$ & Jenness, 1980 \\
\hline 1982 & $\begin{array}{l}\text { Formal evaluation of lipid distribution of goat milk is published; first } \\
\text { research to report differences in cow and goat lipoprotein lipase and } \\
\text { the influence on goat milk flavor. }\end{array}$ & $\begin{array}{l}\text { Cerbulis et al., 1982; DeFeo et al., } \\
1982\end{array}$ \\
\hline 1986 & $\begin{array}{l}\text { Bacterial counts do not explain higher SCC counts in goat milk than cow } \\
\text { milk. }\end{array}$ & Park and Humphrey, 1986 \\
\hline 1989 & $\begin{array}{l}\text { Evidence shows that adulteration of goat and sheep cheeses is } \\
\text { happening worldwide. }\end{array}$ & Iverson and Sheppard, 1989 \\
\hline 1991 & $\begin{array}{l}\text { First evidence shows that goat milk could be divided into low-, medium-, } \\
\text { and high- } \alpha_{\mathrm{s} 1} \text {-casein-producing groups; suggestion that different } \\
\text { genetic variants might influence the } \alpha_{\mathrm{s} 1} \text {-casein expressed phenotype. } \\
\text { Branched-chain FA, including 4-ethylocatanoic (goat-like or "goaty") and } \\
\text { 4-methyloctanoic (mutton-like) acids, from goat and sheep milks are } \\
\text { shown to provide distinguishing flavors to varietal cheeses. }\end{array}$ & $\begin{array}{l}\text { Mora-Gutierrez et al., 1991; Ha } \\
\text { and Lindsay, } 1991\end{array}$ \\
\hline 1993 & $\begin{array}{l}\text { First studies characterize and genotype variance of caprine K-casein; } \\
\text { total fatty acid profiles of cow and goat colostrum are quantified and } \\
\text { significant species are differences found. }\end{array}$ & Coll et al., 1993; Attaie et al., 1993 \\
\hline 2006 & $\begin{array}{l}\text { Transgenic goats are used to express human lysozyme to enhance } \\
\text { antimicrobial properties of goat milk. Genetic research reveals at least } \\
16 \text { alleles are associated with different rates of } \alpha_{\mathrm{s} 1} \text {-casein synthesis in } \\
\text { goats. }\end{array}$ & $\begin{array}{l}\text { Maga et al., 2006a,b; Caroli et al., } \\
2006\end{array}$ \\
\hline 2011 & $\begin{array}{l}\text { Goat milk allergenicity is shown to be a function of } \alpha_{\mathrm{s} 1} \text {-casein genetic } \\
\text { polymorphism; different } \alpha_{\mathrm{s} 1} \text {-casein goat milk genotypes could serve as } \\
\text { protein source for hypoallergenic formulas. }\end{array}$ & Ballabio et al., 2011 \\
\hline 2014 & $\begin{array}{l}\text { Studies confirm that goat milk products may not be suitable for cow } \\
\text { milk-allergic patients due to cross-reactivity of goat lgE antibodies with } \\
\text { cow milk caseins. }\end{array}$ & Lisson et al., 2014 \\
\hline 2016 & Proteomics is used to evaluate adulteration of goat milk with cow milk. & Chen et al., 2016 \\
\hline
\end{tabular}

